\title{
'COSMOVILLAGERS' AS SUSTAINABLE RURAL DEVELOPMENT ACTORS IN MOUNTAIN HAMLETS? INTERNATIONAL IMMIGRANT ENTREPRENEURS' PERCEPTIONS OF SUSTAINABILITY IN THE LLEIDA PYRENEES (CATALONIA, SPAIN)
}

Ricard Morén-Alegret ${ }^{1}$, Josepha Milazzo², Francesc Romagosa ${ }^{3}$, Giorgos Kallis ${ }^{4}$

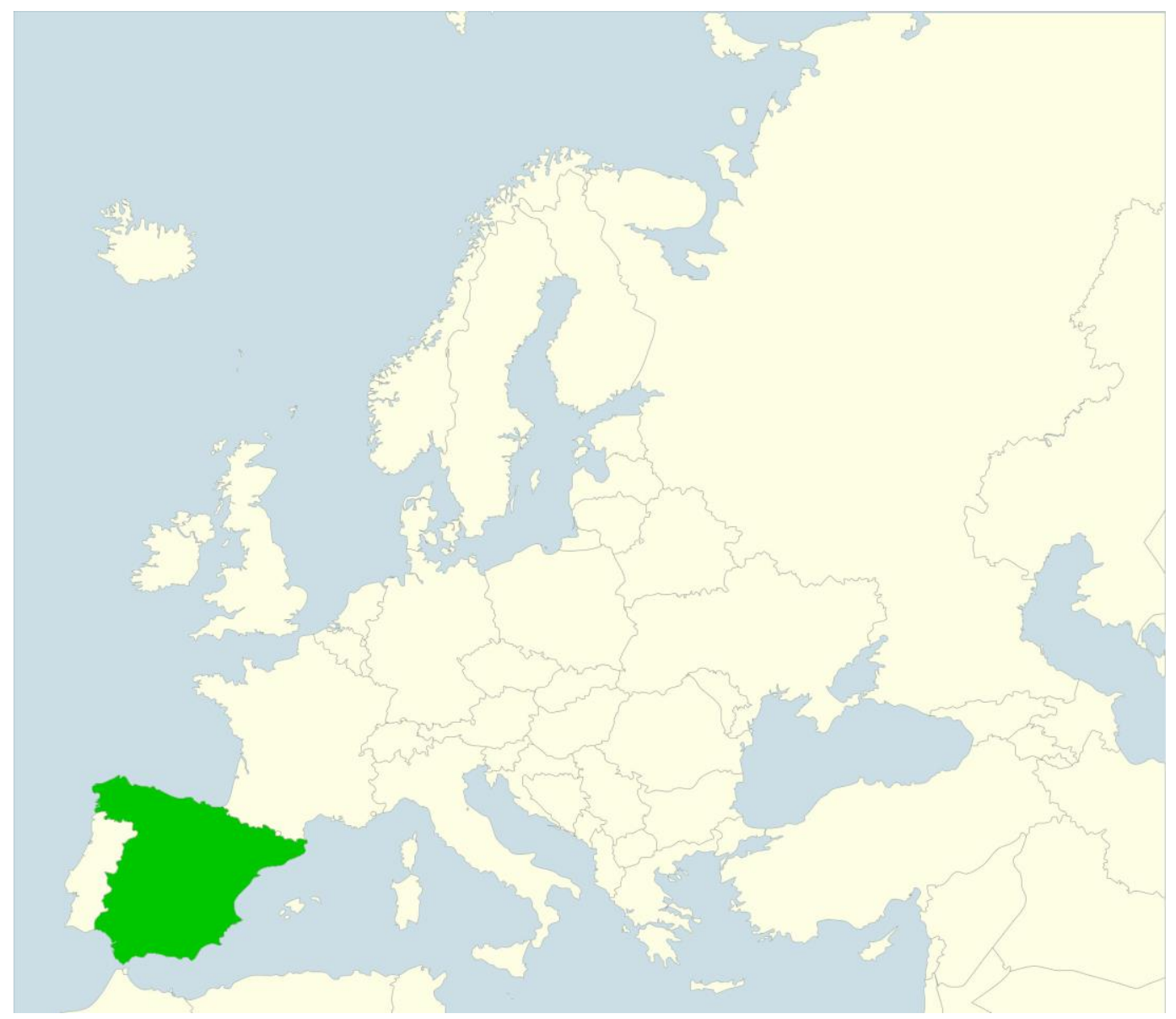

\footnotetext{
${ }^{1}$ Ricard Morén Alegret, Autonomous University of Barcelona, Spain, and IGOT of Lisbon University, Portugal; e-mail: Ricard.Moren@uab.cat, ORCID: 0000-0002-1581-7131

2 Josepha Milazzo, University Aix-en-Provence, France; e-mail: josepha.milazzo@yahoo.fr, ORCID: 0000-0002-44394705

${ }^{3}$ Francesc Romagosa Casals, Autonomous University of Barcelona, Spain; e-mail: francesc.romagosa@uab.cat, ORCID: 0000-0002-9963-4227

${ }^{4}$ Giorgos Kallis, Autonomous University of Barcelona, Spain, and ICREA, Spain; e-mail: Georgios.Kallis@uab.cat, ORCID: 0000-0003-0688-9552
} 
Abstract: In recent decades, small villages in some mountainous regions in Europe have been suffering from ageing and depopulation, yet at the same time, immigrants have been arriving and settling there. This paper sheds light on the perceptions of sustainable rural development among international immigrants living in municipalities with fewer than 500 inhabitants, which are already the home to some 'cosmovillagers'. If immigrants' views are left unattended, an important part of reality will be lacking in the picture of mountainous areas because today immigration is qualitatively relevant in rural Europe. This paper aims to answer the following questions, among others: What dimensions of sustainability are underscored? What are the main challenges for sustainability and the proposals for improvement? What are the local sustainability challenges? This paper provides research results and insights based on original data gathered during fieldwork in the Pyrenees as well as analyses of documents, maps and statistics. Specifically, the main focus is on some several sparsely populated areas in the Lleida Pyrenees, e.g. dozens of municipalities in Alt Urgell, Cerdanya, Pallars Sobirà and Val d'Aran. Thus this paper aims to help fill that relative gap in the existing academic literature by offering original qualitative information.

Keywords: Mountainous Europe, sustainable rural development, human repopulation, international immigrants, small villages, hamlets, cosmovillagers, rural cosmopolitanism

\section{Highlights:}

- Immigration is qualitatively relevant for sustainability in hamlets of the Lleida Pyrenees

- Immigrant entrepreneurs can be cosmovillagers, rural cosmopolitans and/or nationalistic actors

- Land abandonment, sewage disposal and forest management are perceived as environmental challenges

- Seasonality, DIY culture, diversification, ICT and internationalisation are perceived as economic challenges

- Ageing, racism, lack of housing and scarce rural schools are perceived as social challenges

\section{Introduction}

"Could you on this fair mountain leave to feed And batten on this moor?" (William Shakespeare, Hamlet, III, 4)

In William Shakespeare's complete works, one can find at least 71 direct references to 'mountain' or related terms, including a few mentions of them in The Tragedy of Hamlet, Prince of Denmark. In the English language, hamlet means 'small village', yet Hamlet is also the main character in that existential Shakespearean tragedy. In parts of Britain, 'hamlet' may mean a village without a church of its own, but this paper adheres to the general meaning of 'hamlet' in the English language: any little village in the countryside. Specifically, the focus is on hamlets located within municipalities with fewer than 500 inhabitants. In many regions in Europe, sustainable development in small villages is under threat, due to factors like depopulation and ageing, which make these (often rural) places more vulnerable to natural hazards (e.g., wildfires), uncontrolled speculation or abandonment (e.g., Badia et al., 2014; González Hidalgo et al., 2014). However, in some villages, including in various mountainous areas, immigration (both internal and international) can be part of the solution to these problems. The potential of international immigrants for preventing (or at least slowing down) depopulation has been increasingly 
recognised in the literature (Bayona-i-Carrasco \& Gil-Alonso, 2013; Woods, 2016; Morén-Alegret, 2008; Camarero \& Sampedro, 2019; Mendoza et al., 2020). The arrival of international immigrants to rural areas has been a critical part of agricultural restructuring and wider socio-political and economic transformations. This has led to profound changes in some villages across Europe. A growing body of literature examines a range of different types of international immigrants in rural areas, including those working in agri-food or tourism, life-style/amenity immigrants and refugees (e.g. Bartoš et al., 2009; McAreavey, 2017; Morén-Alegret \& Wladyka, 2019; Mendoza et al., 2020).

In this context of both rural depopulation concerns and international immigration arrival in some southern European countries, including Spain (Bayona \& Gil, 2013; Camarero \& Sampedro, 2019), a relatively new term has been circulating in some regional mass media and rural fairs: 'cosmopueblita' (e.g., Fuertes, 2019). This neologism can be translated into English as 'cosmovillager' and has also been spread by geographers (e.g., Benedí, 2019) as a positive term. They view 'cosmovillagers' as active inhabitants aiming to revive rural areas and who are open to the world, including both some well-travelled people born in the village and some newcomers from other regions and nations ${ }^{5}$. This social and economic openness can be related to the development of internationalised sectors like export agriculture or stockbreeding and international tourism (Lampič \& Mrak, 2012; Morén-Alegret \& Wladyka, 2019; Perlik \& Membretti, 2018; Tulla, 2019; Romagosa et al., 2020). 'Cosmovillager' is complementary to the term 'rural cosmopolitism', which first appeared in academic journals some years ago (e.g., Cid-Aguayo, 2008 ) in relation to different places around the world, both in coastal areas and in inland lowlands and mountains (Milazzo, 2015; Morén-Alegret \& Wladyka, 2019). According to Cid-Aguayo's (2008) distinction between global and globalised places, both key interregional and international connections and real relations can help to foster active 'global villages' instead of passive 'globalised villages'. In brief, in some types of globalisation, local leaders and inhabitants can lose and no longer control their village's space (globalised villages), or conversely, the inhabitants can take advantage of globalisation in order to sustainably develop their living space (global villages). Thus, in each case, capital, cultural products and symbols can alter the livelihoods of villagers in different ways. In this sense, it is important to highlight that social relations among a variety of inhabitants are key components of rural and mountain sustainability, including international social relations (McAreavey, 2017; Morén-Alegret \& Wladyka, 2019; Woods, 2016).

Thus, 'cosmovillagers' can actively foster sustainable and active global villages instead of just contributing to urbanising the countryside like some 'rural cosmopolitans' may be doing in many ways. The concept of 'polis' included in the term 'cosmopolitan' comes from the ancient Greek term for city, while 'cosmovillager' highlights the importance of the village as a small human population settlement that can also be connected to most of the greater world, in that the term 'cosmos' also comes from ancient Greek and means the (ordered) world. However, this study does not assume that 'cosmovillagers' are those who do 'good' things (producing global villages), unlike rural cosmopolitans. In reality, distinctions might not be sharp and the same people might do a variety of actions, or they might do one thing, which depending on how things go might evolve into a context of globalised village or global village (assuming also that the two can be sharply distinguished). This paper does not judge persons or places, but explores on-going complex processes and gives voice to international immigrant entrepreneurs.

Some rural areas in a variety of European Union (EU) countries today are the home to more international migrants than others. As Charalambos Kasimis (2010) stated, Spain is one of the southern European countries known for its relatively long experience of hosting international immigrants in villages, particularly in some inland lowlands and low mountainous regions located relatively near the coast (Morén-Alegret \& Wladyka, 2019; Mendoza et al., 2020). However, less attention has been paid to international immigrants living in some higher mountainous regions located further from the coast, as in some hamlets in the Lleida Pyrenees, a mountainous area in northern Spain (e.g., Solé, 2013) that borders on France and Andorra. Some of these newcomers can be considered 'cosmovillagers' and/or rural cosmopolitans, and they may be contributing to

\footnotetext{
5 This does not necessarily include though all immigrants and there might be a 'class', entrepreneurial or income dimension.
} 
the urbanisation and the internationalisation of the countryside (Halfacree, 2008), as well as to the revival of rural or natural areas (Connel \& McManus, 2011).

The aforementioned changes in the European countryside occur while a variety of actors try to incorporate the seventeen United Nations (UN)' Sustainable Development Goals (SDGs) in policies at local, regional, national and international level. These SDGs should be achieved by year 2030 worldwide. ${ }^{6}$ The 2 nd SDG of the 2030 UN Development Agenda pays explicit attention to rural issues (UN, 2015; Morén-Alegret \& Wladyka, 2019). Additionally, within the context of the EU, the importance of people-centred rural development and promotion of sustainable food production systems have been underscored (EUROSTAT 2016; 2017), while FAO (2018) has noted that 'one of the key challenges facing sustainable rural development is information sharing and dissemination'. In this sense, as stated in a report on migration and 2030 SDGs agenda (Mosler Vidal, 2018; p. 31), 'data gaps include the impact of migration policy, migratory movements to and from rural areas' (Morén-Alegret \& Wladyka, 2019). In addition, if international immigrants' views are left unattended, an important part of reality will be lacking in the picture of mountainous and rural areas because today immigration is qualitatively relevant in rural Europe (Woods, 2016; Morén-Alegret \& Wladyka, 2019). Particularly, international immigrant entrepreneurs living in rural areas are a relatively under-researched group that can contribute to sustainable development, creativity and innovation (Kalantaridis and Bika, 2011; Carson et al., 2018; Mendoza et al., 2020).

Thus, this paper aims to help fill that relative gap in the existing academic literature on immigration in rural mountainous regions. Specifically, bearing the 2030 SDGs in mind, this paper sheds light on the perceptions of international immigrant entrepreneurs living in hamlets in the Lleida Pyrenees: What dimensions of sustainability are underscored? What are the main challenges for sustainability and the proposals for improving human life in the mountains? What are the local sustainability challenges? This paper offers answers to these and other related questions by providing research results and insights mainly based on original qualitative interview data gathered during fieldwork in the Pyrenees, as well as analyses of documents, maps and official statistics.

\section{Theoretical and conceptual background on sustainability, human depopulation and repopulation in European mountains}

Some mountainous regions with 'genius loci' have a potential competitive advantage as desirable destinations for (entrepreneurial) immigrants, as their socio-cultural, natural and economic attributes may be appropriate to commodify and revalorise the place (Bartoš et al., 2009). In parts of Europe, including the Lleida Pyrenees, the consumption of mountain municipalities as 'touristic products' where one can 'disconnect' is widely promoted by some governments and private companies in order to attract visitors from big cities to rural territories (Mármol, 2019). However, territories are not (only) (commodity) products, but also processes comprised of a range of perceptions, practices and techniques, including bordering, enclosing, excluding, surveying and mapping (Elden, 2018). Mountainous territories have been inhabited by a wide variety of human populations throughout history and prehistory, and urban prejudices about them are diverse as well. The relatively recent huge literary success of James Rebanks (2015), a mountain shepherd himself, underscores a paradoxical situation: depending on the point of view, the area in which he lives has been considered 'poor, unproductive, primitive, harsh, ugly and backward' or, in contrast, 'beautiful', 'stimulating', 'ideal' and 'a model for a good society' (Morén-Alegret \& Wladyka, 2019). Somehow, this paradox can also be found in several other literary places, including William Shakespeare's complete works (see Bate \& Rasmussen, 2007): mountains can be linked to stereotypical ill-mannered cave-dwellers as in Twelfth Night, as well as to rich agricultural fields in The Tempest, which is apparently the last play William Shakespeare wrote.

In any case, today, mountainous areas are crucially connected to different debates and challenges within the sustainable development agenda (e.g., FAO, 2011: 5): "Harsh climatic and environmental conditions, remoteness and often difficult access hamper development in

\footnotetext{
${ }^{6}$ See: https://sustainabledevelopment.un.org
} 
mountain regions... Mountain communities live far from the centres of commerce and power, so they have little influence on the policies and decisions that affect their lives, and their voices often go unheard".

The term 'sustainable' comes from Latin sustinere (made of sub + tenere: hold, keep) and, as William Shakespeare poetically suggested in Timon of Athens, 'to prevent' is useful in order to 'sustain' our 'uncertain' human life and the challenges that emerge on earth (Morén-Alegret \& Wladyka, 2019). These challenges may include the environmental, cultural and socio-economic impact of human depopulation in rural and mountainous areas (Queralt, 1999; Macfarlane, 2015; Lardiés, 2018). Thus this paper aims to prevent the voices of various mountain inhabitants born abroad from continuing to be unheard and instead allow them to inform policy-makers, academics and other readers interested in immigration in mountainous areas. If immigrants' views are left unattended, an important part of reality will be lacking in the picture of mountainous areas because today immigration is forging a 'new reality' in different places in rural Europe (Woods, 2016). This is true for both immigrant women and men, and for both internal and international immigrants. For instance, in 2019, a fair named 'La Cosmopueblita' was organised as the Rural Life Fair (in a positive sense) in Burbáguena, a hamlet in Teruel province (Aragon, Spain). The Southern Sparsely Populated Areas network (SSPA) supported the fair. Its first edition was dedicated to Rural Women and discussed experiences undertaken by young entrepreneurs, businesswomen, cultural promoters, media professionals, rural policy-makers and artists. ${ }^{7}$ As suggested at that time, sustainability and creativity go hand in hand and involve both rural natives and newcomers.

The concept of 'sustainability' is a neologism, the brainchild of the nature conservation movement, illustrating the shift from 'wildlife conservation' to a broader movement in favour of a healthy planet, including humans in the debate (UN, 2015). In general terms, there is a fundamental emphasis in sustainability discourse on interconnectedness and unity (Adams, 2006; Becker et al., 1997). On striving not to "uproar the universal peace, confound / All unity on earth" (William Shakespeare's Macbeth, IV, 3). In this regard, sustainability - the commitment to the long-term continuity of what is valued, keeping the best of what is already there but allowing and often promoting certain types of change - must be seen as always sitting in the midst of 'social', 'economic' and 'environmental' considerations, with any displacement into just one sector, such as 'economic sustainability', leading to a loss of this holistic approach (e.g. Adams, 2006; MorénAlegret \& Wladyka, 2019). Thus human population studies, including immigration studies, should be part of the sustainability debates about the mountainous areas of the future. Authors like Perlik and Membretti (2018) have focused on how the new trends in lifestyle migrations into rural mountainous regions like the Alps are embedded in global value chains by promoting economic regeneration. Therefore, those migrants bring purchasing power into their communities and are desirable assets for some local governments and businesses (Morén-Alegret \& Wladyka, 2019). However, sometimes there is also a lack of broader local dialogue that would result in a more sustainable approach to this phenomenon. Mountains can be 'commodified' as landscape products creating the so-called 'rural idyll' for amenity migrants (Gretter et al., 2017), or, as Benson \& Osbaldiston (2014) put it, lifestyle migrants. In that case, newcomers are related to purchasing power or investment and diversification rather than labour migration. This kind of migration, especially if managed in a sustainable manner, has the potential to improve rural economies (Morén-Alegret \& Wladyka, 2019; Romagosa et al., 2020). However, Perlik and Membretti (2018) discuss several challenges related to this type of migration, especially longterm effects on inflated property prices and the displaced local working class because of the gentrification process they induce. Subsequently, the failure to sustainably manage diversity can trigger conflicts and impose competition between natives and immigrants. Often the ingroup/out-group mentality plays a part in whether newcomers are accepted or rejected. Perlik and Membretti (2018) indicate that societal strategies like a welcoming culture can eliminate the negative lens that perceives migrants as disturbing and therefore excluded. Yet, that is not necessarily straightforward because, unlike urban locations, in the past, many rural areas did not view immigration as beneficial or bringing new knowledge (Morén-Alegret \& Wladyka, 2019). In

\footnotetext{
7 See: http://sspa-network.eu/en/the-cosmopueblita-the-fair-of-the-positiveness-of-rural-life/
} 
addition, Gretter et al. (2017) also analyse immigration management in European mountainous areas by highlighting the different types of migrants that have arrived mostly in the $21^{\text {st }}$ century, including amenity migration, tourism workers, economic migrants, as well as refugees and asylum seekers. Government, non-profit, and private actors play a prominent role alongside policy. Importantly, Gretter et al. (2017) stated that successful welcome and inclusion processes are not only social (supportive social environment, development of the relationships with local agents focused on bridging the gap between the groups), but also environmental and spatial, including appropriate locations for immigrants to settle and find support (Morén-Alegret \& Wladyka, 2019).

In contrast to other European mountain ranges like the Alps, or to other parts of the Pyrenees (e.g., for the French Pyrenees see: Berthomière \& Imbert, 2020), there are relatively few studies or books about recent human population changes (e.g. Aldomà, 2015; Bielza de Ory, 1993; Guirado \& Tulla, 2010; Ordi et al. 2015; Soriano et al., 1994) and immigration in the Lleida Pyrenees (e.g., Luvich \& Ortega, 2004; Solé, 2013). Thus, this paper aims to help fill that relative gap by offering original qualitative information about international immigrants' perceptions of the current environmental, economic and social sustainability challenges in the Lleida Pyrenees.

\section{Methodology, research methods, data sources and region studied}

This article is based on the research project titled "HAMLETS: Immigration and Sustainable Development in Small Villages", 8 which mainly focuses on Catalonia (Spain). This project aims to contribute to improving territorial relations and integration in Catalonia beyond the so-called ruralurban divide (Champion \& Hugo, 2004) within the context of a changing, multi-related world. The project methodology consisted in multi-sited research that relies on both quantitative and qualitative methods and techniques applied to carefully pre-selected case studies. The project is based on previous epistemological work and previous practical experience on migration and geoenvironmental studies carried out by the research team (e.g. Kallis et al., 2013; Mendoza \& Morén-Alegret, 2013). Its sources of inspirations include humanistic geography and political ecology. This article studies foreign-born immigrants and sustainability in municipalities with fewer than 500 inhabitants (i.e., 'micro-villages' or hamlets), following the definition used by the Guild of Geographers of Catalonia (Col-legi de Geògrafs, 2013), the Catalan Association of Small Villages and some regional publications, e.g., Serena \& Bayer, 2016 (Mendoza et al., 2020; Romagosa et al., 2020). According to official statistics, 337 out of the 947 municipalities in Catalonia have fewer than 500 inhabitants. While these sparsely populated municipalities comprise over one-third (36\%) of the Catalan municipalities and land (INE, 2018), only $1.08 \%$ of the Catalan population resides in them. In this regard, Map 1 shows the location of these 337 sparsely populated municipalities in Catalonia as a whole (they are located mainly in mountainous and inland areas) as well as the percentage of foreign-born residents living in them, which in a few cases can be upwards of almost one-third of the population.

\footnotetext{
${ }^{8}$ See: http://atlantis.uab.cat/hamlets/en/index.html
} 


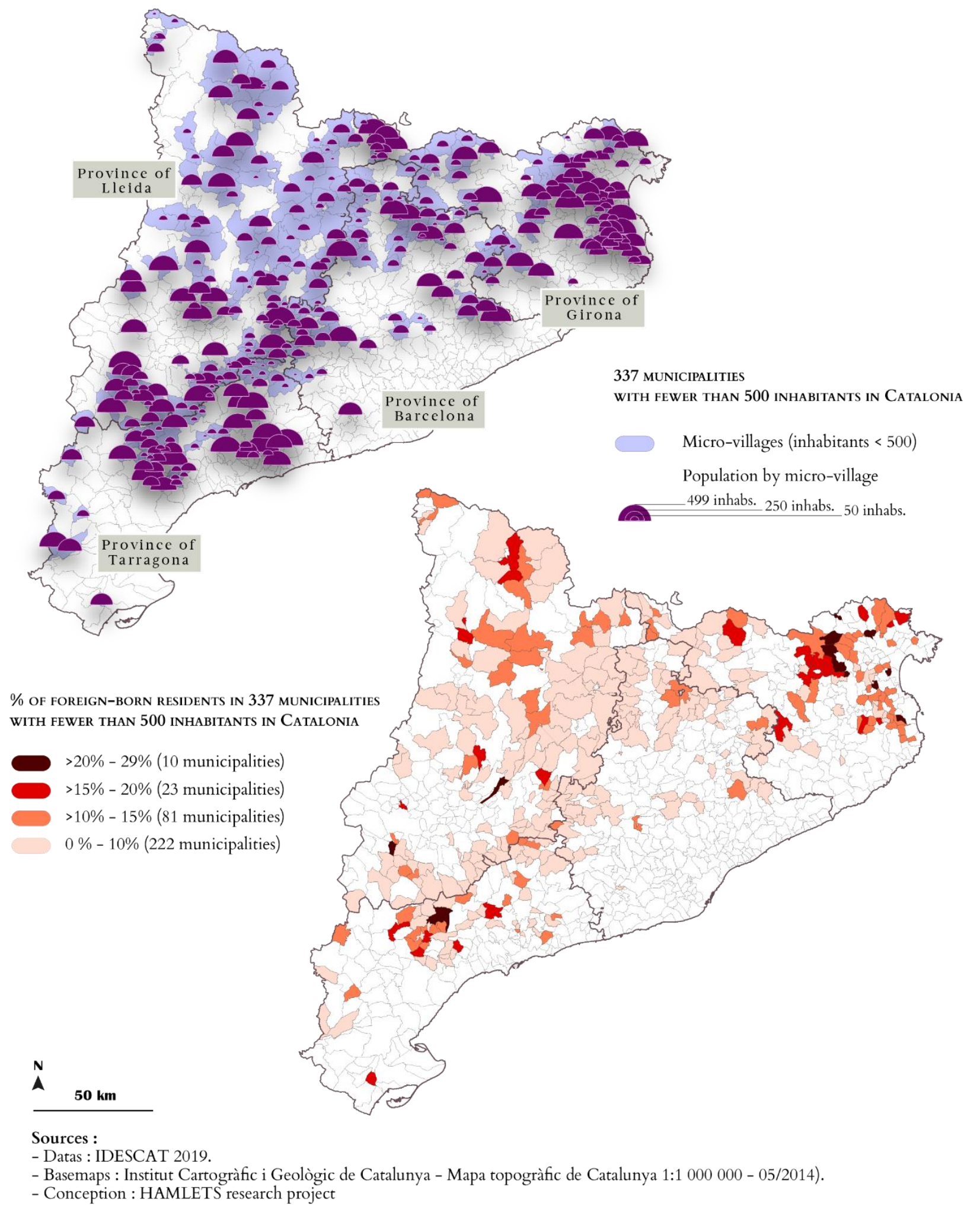

Fig 1. Foreign-born residents in 337 municipalities with fewer than 500 inhabitants in Catalonia. 


\subsection{Region studied: the Lleida Pyrenees}

In Spain, the 50 provinces are the key territorial unit recognised in the 1978 Constitution for the country as a whole, and provincial governments (Diputaciones Provinciales) are particularly important public administrative bodies for municipalities with fewer inhabitants. In addition, in Catalonia (and in some other of the 17 Spanish autonomous regions), county councils (consells comarcals / consejos comarcales) are also important in managing some public services in sparsely populated municipalities.

In this paper, the focus is on Lleida province, one of the Spanish provinces with a relatively low population density and the Catalan province with the lowest population density. The Lleida Pyrenees are situated in northwest Catalonia (an autonomous region in north-east Spain), and as also shown in Map 1, they are home to several small villages with a significant number of international immigrants. Specifically, the case study on which this paper is based focused on municipalities in the three mountainous counties (or comarcas) that have significant amounts of 'micro-villages' located in Lleida province (see Map 2): firstly, Alt Urgell (12 out of 19 municipalities), whose county capital is La Seu d'Urgell; secondly, Pallars Sobirà (12 out of 15 municipalities), whose county capital is Sort; and, thirdly, Val d'Aran (5 out of 9 municipalities), whose capital is Vielha. In addition, attention was paid to the four municipalities in the Cerdanya comarca that belong to Lleida province (the rest of that county belongs to the Spanish Girona province in Spain and the Eastern Pyrenees Department in France). Last but not least, attention was also paid to Gósol, a municipality in Berguedà county belonging to Lleida province as well (the rest of Berguedà belongs to Barcelona province in Spain). At territorial level, both Spanish and Catalan are co-official languages in Catalonia as a whole, but Val d'Aran is an officially trilingual region where Occitan is also co-official. Thus, the fieldwork was conducted in a multilingual context.

The counties of Alt Urgell, Cerdanya, Pallars Sobirà and Val d'Aran share an international border with France, and Alt Urgell and Pallars Sobirà also share an international border with Andorra, which is not yet a EU member. As shown in Table 1, during the period 1990-2016, the hamlets in Alt Urgell lost population (422 fewer inhabitants, that is, in year 2016, the population was $15.5 \%$ lower than in 1990), but the rest of the territories in Lleida Pyrenees have gained inhabitants, mainly due to immigration. In absolute numbers and general terms, in 2016, the hamlets in Pallars Sobirà had a higher number of foreign-born residents (266) than the others, but, in relative numbers, the hamlets in Alt Urgell had a higher average percentage of foreign-born residents $(10.6 \%)$ than the other territories studied here. However, that percentage is still much lower than the average number of foreign-born residents in Lleida province as a whole (18\%), which is a symptom of the mountains' difficulties for attracting and retaining international immigrants. Regarding places of birth, most immigrants in the hamlets in the Lleida Pyrenees come from other European countries (mainly from other EU member states) and from the Americas, primarily South America. Thus, our main focus in this case study is on immigrants with these two geographical origins. Interestingly, the number of immigrants born in Africa is scarce in the Lleida Pyrenees, but in Lleida province as a whole the number of EU immigrants is similar to the number of African immigrants (these population groups each encompass more than 27,000 residents each). In contrast, in Lleida province as a whole, the number of immigrants born in the Americas is significantly lower than EU immigrants and African immigrants (15,055 residents). It should be taken into account that some ski resorts in the Pyrenees recruit immigrant workers from mountainous areas in South America, and some of them may later settle in the Pyrenees as entrepreneurs. 


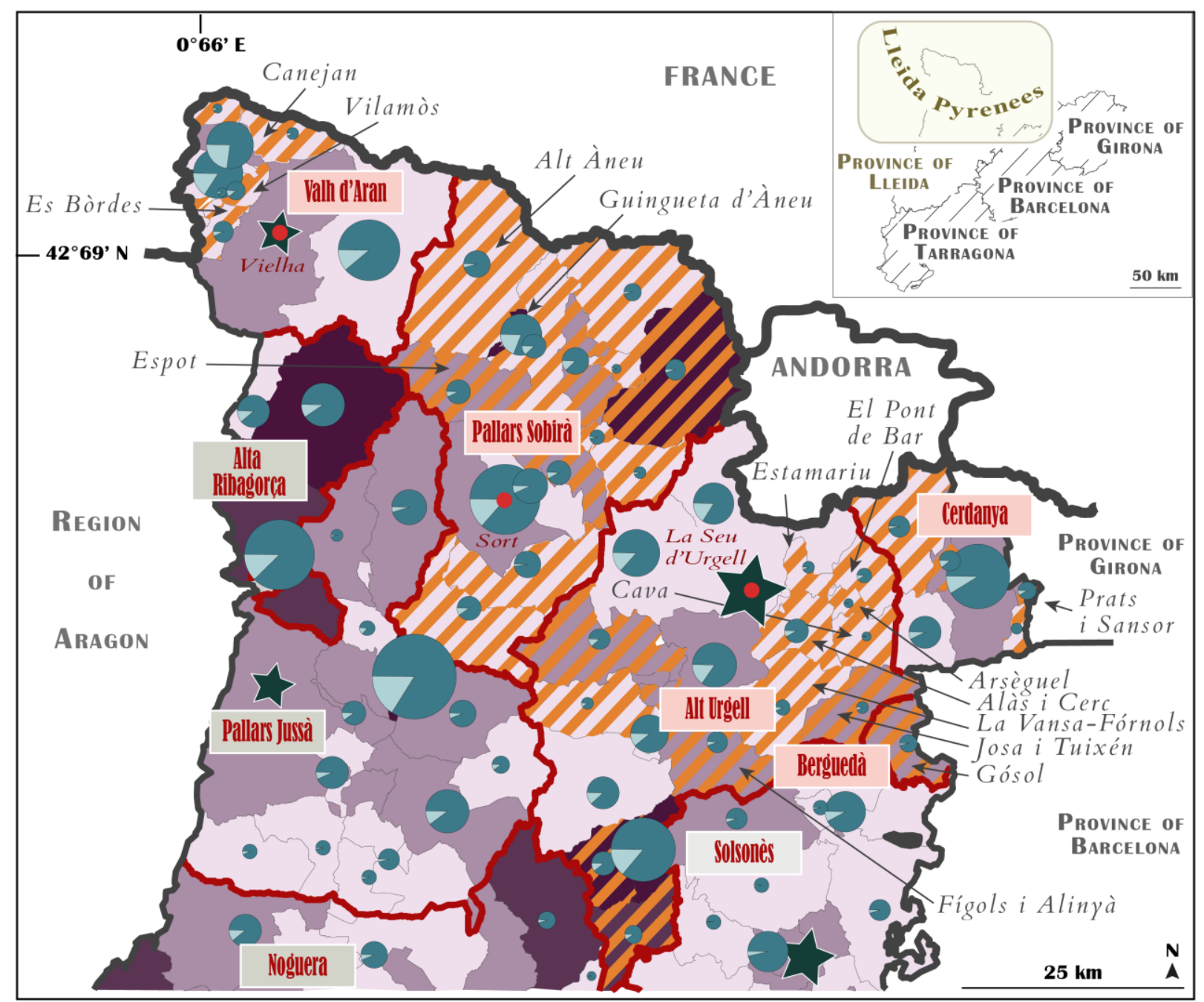

\begin{tabular}{|c|c|}
\hline Vallh d'aran & Investigated counties \\
\hline Pallaris Jussà & Other counties \\
\hline & Counties' limits \\
\hline$\stackrel{\ominus}{\text { Vielha }}$ & $\begin{array}{l}\text { Capital of main } \\
\text { investigated counties }\end{array}$ \\
\hline 72 & $\begin{array}{l}\text { Micro-villages ( }<500 \text { inhabs.) } \\
\text { of investigated counties }\end{array}$ \\
\hline & $\begin{array}{l}\text { International limits } \\
\text { Provincial limits } \\
\text { Municipalities' limits }\end{array}$ \\
\hline & $\begin{array}{l}\text { Location and name } \\
\text { of municipalities of hamlet }(\mathrm{s})\end{array}$ \\
\hline
\end{tabular}

Population By MUNiCipaLity (2019)

(ONIY MUNICIPALITIES WITH < 5000 INHABS. ARE REPRESENTED) :

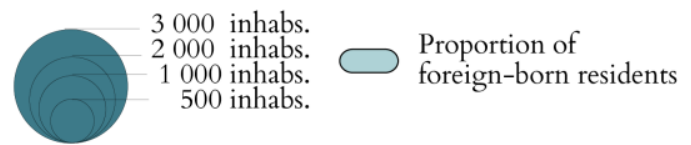

Municipalities with 5000 to $<13000$ inhabs. :

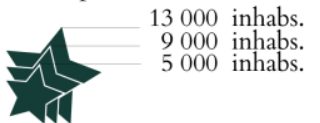

DECREASE OR INCREASE IN THE NUMBER OF FOREIGN-BORN RESIDENTS IN THE LOCAL POPULATION BY MUNICIPALITY (BETWEEN 1999 AND 2019) :

No presence in 1999, but in 2019 / or presence multiplied up to 5 times
Presence multiplied between 5 to 10 times
Presence multiplied between 10 to 15 times
Presence multiplied between 15 to 30 times

Sources :

- Data : IDESCAT 2019.

- Basemaps : Institut Cartogràfic i Geològic de Catalunya - Mapa topogràłic de Catalunya 1:1 000000 - 05/2014).

- Conception : HAMLETS research project

Fig 2. Location of municipalities with fewer than 500 inhabitants in the Lleida Pyrenees. 
Tab 1. Total registered resident population in hamlets (municipalities with fewer than 500 inhabitants) in the Lleida Pyrenees (1990-2016) and by place of birth (2016). Source: HAMLETS research project based on INE's Continuous Census

\begin{tabular}{|c|c|c|c|c|c|c|c|c|c|}
\hline $\begin{array}{c}\mathbf{N}^{\circ} \text { of Lleida } \\
\text { municipalities } \\
\text { in study } \\
\text { counties }\end{array}$ & $\begin{array}{c}\text { Total } \\
\text { residents } \\
\text { in 1990 }\end{array}$ & $\begin{array}{c}\text { Total } \\
\text { residents } \\
\text { in 2016 }\end{array}$ & $\begin{array}{c}\text { Born } \\
\text { Abroad } \\
\mathbf{( 2 0 1 6 )}\end{array}$ & $\begin{array}{c}\text { \% Born } \\
\text { abroad } \\
\mathbf{( 2 0 1 6 )}\end{array}$ & $\begin{array}{c}\text { Born in } \\
\text { Europe } \\
\text { as a } \\
\text { whole } \\
(2016)\end{array}$ & $\begin{array}{c}\text { Born } \\
\text { in the } \\
\text { EU } \\
(2016)\end{array}$ & $\begin{array}{c}\text { Born in } \\
\text { Africa } \\
(2016)\end{array}$ & $\begin{array}{c}\text { Born in } \\
\text { Americas } \\
(2016)\end{array}$ & $\begin{array}{c}\text { Born in } \\
\text { Asia \& } \\
\text { Oceania } \\
(2016)\end{array}$ \\
\hline $\begin{array}{c}\mathbf{1 2} \text { mun. of Alt } \\
\text { Urgell }\end{array}$ & 2725 & $\mathbf{2 3 0 3}$ & $\mathbf{2 4 4}$ & $\mathbf{1 0 . 6 \%}$ & 169 & 122 & 11 & 61 & 2 \\
\hline $\begin{array}{c}\mathbf{1 2} \text { mun. of } \\
\text { Pallars Sobirà }\end{array}$ & 2918 & $\mathbf{3 3 8 3}$ & $\mathbf{2 6 6}$ & $\mathbf{7 . 8 \%}$ & 145 & 128 & 31 & 80 & 10 \\
\hline $\begin{array}{c}\mathbf{5} \text { mun. of Val } \\
\text { d'Aran }\end{array}$ & 537 & $\mathbf{6 2 6}$ & $\mathbf{5 1}$ & $\mathbf{8 . 1 \%}$ & 34 & 34 & 4 & 13 & 0 \\
\hline $\begin{array}{c}\mathbf{4} \text { mun. of } \\
\text { Cerdanya }\end{array}$ & 611 & $\mathbf{7 9 0}$ & $\mathbf{6 5}$ & $\mathbf{8 . 2 \%}$ & 27 & 26 & 3 & 34 & 1 \\
\hline $\begin{array}{c}\mathbf{1} \text { mun. of } \\
\text { Berguedà }\end{array}$ & 203 & $\mathbf{2 2 8}$ & $\mathbf{4}$ & $\mathbf{1 . 7 \%}$ & 4 & 3 & 0 & 0 & 0 \\
\hline $\begin{array}{c}\text { Total Lleida } \\
\text { Pyrenees }\end{array}$ & 6994 & $\mathbf{7 3 3 0}$ & $\mathbf{6 3 0}$ & $\mathbf{8 . 5 \%}$ & 379 & 313 & 49 & 188 & 13 \\
\hline $\begin{array}{c}\text { Total Lleida } \\
\text { province }\end{array}$ & 354142 & $\mathbf{4 3 4 0 4 1}$ & $\mathbf{7 8 4 2 9}$ & $\mathbf{1 8 \%}$ & 33466 & 27939 & 27161 & 15075 & 2727 \\
\hline
\end{tabular}

\subsection{Research methods and questions}

This article specifically focuses on sustainable rural development in sparsely populated areas and compares the experiences, views and opinions of international immigrants living in small villages. According to Ragin (1994), the three main objectives of qualitative research are to give voice, to interpret significant historical or cultural phenomena, and to propose theory. In this article, the analysis is mainly focused on international immigrants' narratives because their voices have often been neglected in the scholarly literature on sustainability, especially regarding rural and semi-rural areas (Woods, 2016; Morén-Alegret \& Wladyka, 2019). Listening to a variety of immigrants' voices (including those from both wealthier countries and impoverished countries) has the added value of gaining different points of view, which helps us to learn about different contexts of diversity (UNU-GCM, 2015; Morén-Alegret \& Wladyka, 2019). Therefore, as noted above, this article sheds light on the contents of their perceptions: What dimensions of sustainability are underscored? What are the main challenges for sustainability and the proposals for improvement? What are the local sustainability challenges? Exploratory fieldwork (including documental and photographic work) was carried out in all the aforementioned 34 municipalities with fewer than 500 inhabitants in the Lleida Pyrenees and interviews with immigrants were conducted in 8 of them. Immigrants were selected via local/regional organisations, participant observation in villages, spontaneous contacts during fieldwork and the snowballing technique.

The 13 semi-structured interviews with international immigrants ${ }^{9}$ that are analysed here lasted an average of approximately one hour, and they were conducted at a time and place chosen by participants. The interviews were structured along three main dimensions: economic, social and environmental. Participants signed their consent to be interviewed and were assured that the data gathered would be anonymised. To this end, we used codes and pseudonyms. The main aim was not to have a representative sample but to collect a variety of experiences that are qualitatively relevant. All the interviews were audio-recorded during face-to-face physical meetings mostly held along the spring, summer and autumn of 2019 as well as in early 2020. The immigrants interviewed had been residing in municipalities with fewer than 500 inhabitants of the Lleida Pyrenees for at least one year and had been born abroad. Some interviewees were born in other EU countries, while others were born in non-EU countries. The interviews were conducted in

\footnotetext{
${ }^{9}$ Apart from all that, the HAMLETS project upon which this paper is based included also another study area in Girona province where a similar number and variety of interviews were conducted.
} 
a variety of languages: Spanish, Catalan, French, English and Portuguese. When necessary, illustrative interview excerpts recorded in other languages were translated into English. In order to be able to compare responses by sex, geographical origin and age ranges, there is a certain balance between older/younger than 40 years old (6/7), EU and South American immigrants as well as between interviewed men and women, although the latter were given more voice $(5 / 8)$. In each interview quote below, the following details are provided: the immigrant entrepreneurs' main activity dimension/s (SC for social, EC for economic, ENV for Environmental), age (years old), geographical origin (EU for the European Union countries like France, the Netherlands, Romania and Portugal; SA for South American countries like Argentina, Bolivia, Colombia and Peru), gender (female/male); and whether they have descendants at this point (YC for 'yes, s/he does has children'; NC for 'no, s/he does not have children'). In line with other related publications (e.g., Romagosa et al., 2020; Morén-Alegret \& Wladyka, 2019), the interview data were analysed using a content analysis method. During the interviews, the immigrant entrepreneurs identified a number of key essential challenges related to each of the three main sustainability dimensions ${ }^{10}$. These challenges are grouped as follows: a) environmental sustainability: wastewater disposal, woodlands management, wildlife conservation, public transport, roads maintenance, environmental education and climate change; b) economic sustainability: DIY mentality, seasonality, economic diversification, labour conditions and business development, business logistics, Internet connection, bureaucracy and access to support/networks/credit; c) social sustainability: ageing population, rural schools, youth's prospects, entertainment, housing, individualism, isolation, open/closed social life, (second home) part-time inhabitants, municipal politics, prejudice, gossip, racism and sexism. This three-fold approach to sustainability provided novel empirical findings in small villages, while bearing in mind the theoretical concerns of sustainability (see above). To the extent possible, we sought to avoid isolating each dimension or allowing one of them to predominate. Inspired by previous publications on writing qualitative research (e.g., Ely et al., 1997:37), the organisation of the results does not draw strict lines among the components of sustainability but aims to highlight major emerging themes for each sustainability dimension. For example, gender issues can somehow be related to all three dimensions.

\section{Results on challenges and opportunities for immigration in the Lleida Pyrenees: Giving voice to international immigrant entrepreneurs engaged in different sectors}

In this section of the paper, we offer an illustrative sample of the challenges and opportunities that should be taken into account in the present and/or the future to improve policy-making in mountainous regions.

\subsection{Environmental dimension of sustainability}

\subsubsection{Wastewaters disposal, woodlands management and combining wildlife conservation with farming and tourism}

In a way or another, the international immigrants interviewed in the Lleida Pyrenees are proud of the local environment where they live. However, in contrast to the situation in small towns and larger villages where fieldwork was carried out in previous research projects (e.g., Morén-Alegret \& Wladyka, 2019), according to interviewees in hamlets in the Lleida Pyrenees, the lack of sewage disposal is one of the main environmental challenges there: "You can see a lot of junk in the river. After the floods, every year you can see junk... We swim there, but every year the river water is less and less clean. Last summer some toxic algae appeared... it was really polluted. Apparently, some people with holiday homes in the area dumped their wastewaters into the river" (EC\&SC-40-EU-female-YC). This issue affects several small villages in a variety of inland

\footnotetext{
10 In brief, 8 interviews were conducted by R. Morén-Alegret alone; 2 by J. Milazzo and R. Morén-Alegret; 1 by J. Milazzo alone; 1 by F. Romagosa and R. Morén-Alegret; and 1 by L. Mojica \& R. Morén-Alegret.
} 
counties in Catalonia ${ }^{11}$, but as environmental challenge emerges more in interviews with immigrant entrepreneurs than with Spanish-born key informants.

In fact, according to the Catalan Water Agency, about $3 \%$ of the Catalan population and hundreds of villages still have no wastewater treatment plants: in June 2020, the Sanitation Plan of Catalonia included 526 treatment plants that sanitised water for $97 \%$ of the Catalan population ${ }^{12}$. In this context, if one wants to stop (increasing) river pollution, this lack of proper wastewater treatment hinders any serious short-term plans for repopulating sparsely populated municipalities with permanent residents, while also putting any possible sustainable industrial development or entrepreneurial touristic projects there at risk.

Thus, if policy-makers want to encourage human repopulation in the Lleida Pyrenees, all municipalities (and other relevant public authorities) have to be helped to make wastewater treatment a priority in their policy plans. Repopulating hamlets with more human beings instead of other species would avoid land abandonment, which combined with climate change can make (extreme) floods another key environmental challenge, as the words of an immigrant entrepreneur illustrates: "Land abandonment worsens the impact of floods caused by extreme rain ... water with garbage flows down, damaging fields and paths below... some ancient water channels should be restored in order to prevent floods" (EC\&ENV-34-SA-male-NC).

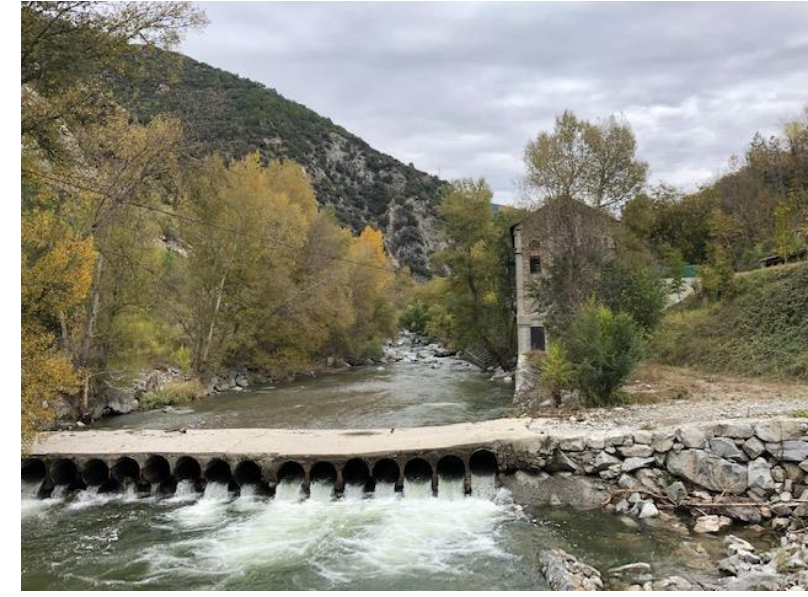

Fig 3. River Segre in Pont de Bar, Alt Urgell (@RicardMoren, 2019)

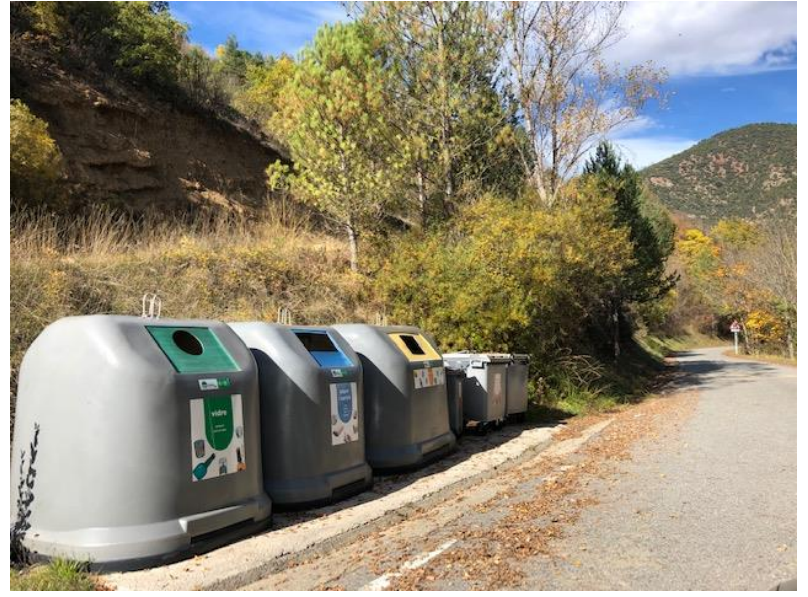

Fig 4. Recycling containers in Cava municipality, Alt Urgell (@RicardMoren, 2019)

In addition, solid waste management is another environmental challenge highlighted, albeit to a lesser extent, in some villages, particularly during peak tourist periods: "Garbage collection is fine in low seasons but overwhelmed in the summer... Containers are far from the village centre. The bar generates a lot of waste during the summer and sometimes containers are full of waste, so some days the bartenders have to carry the waste from the village to the county capital themselves" (EC-43-SA-female-NC).

Some of the immigrant entrepreneurs interviewed in hamlets view forest management as another key environmental challenge for sustainability in order to avoid wildfires: "The woods should be cleaned. It should be a serious project... Some years, the pine trees have been drying out... As volunteer firemen, in the summer we, have been watching the mountains all day in fear" (SC\&EC68-SA-male-YC). In this sense, some immigrant entrepreneurs feel a 'spiritual' responsibility that helps them to lay down roots in the village, as well as in the rural and natural surroundings: "We are the heirs of generations who worked and took care of the land. The land was well kept, but year after year, land abandonment is bringing problems. If there are not goats or sheep, there is more undergrowth" (EC\&ENV-34-SA-male-NC). The importance of woodlands was already acknowledged centuries ago, including in some of William Shakespeare's plays. For instance, in

\footnotetext{
11 See: http://www.pirineustv.cat/2020/06/22/el-pallars-jussa-insta-als-ajuntaments-a-demanar-inversions-endepuradores/ (last accessed 5 November 2020)

12 See: http://aca.gencat.cat/ca//laigua/infraestructures/estacions-depuradores-daigua-residual/index.html
} 
'As You Like It', ${ }^{13}$ Shakespeare shows woodlands and broader pastoral life as productive spaces where 'positive' transformation takes place (Robinson, 2016).

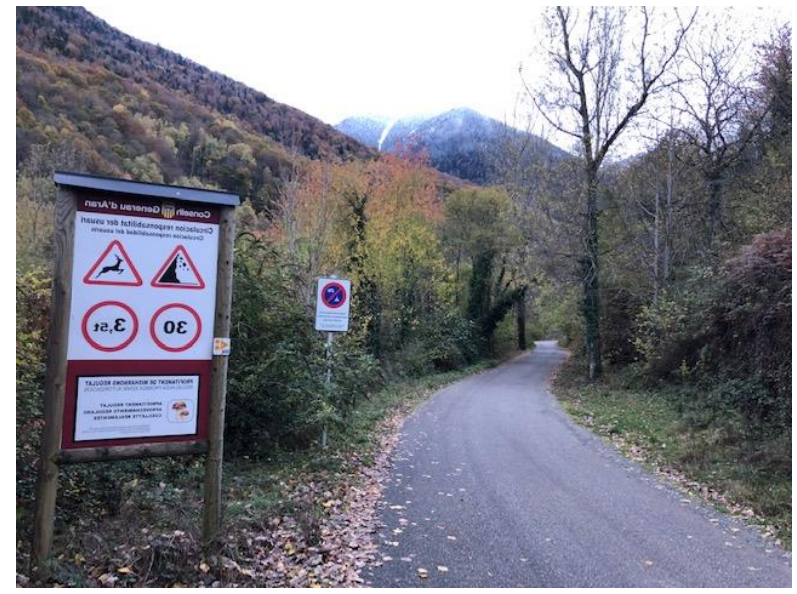

Fig 5. Rural road in woodlands of Val d'Aran (@RicardMoren, 2019)

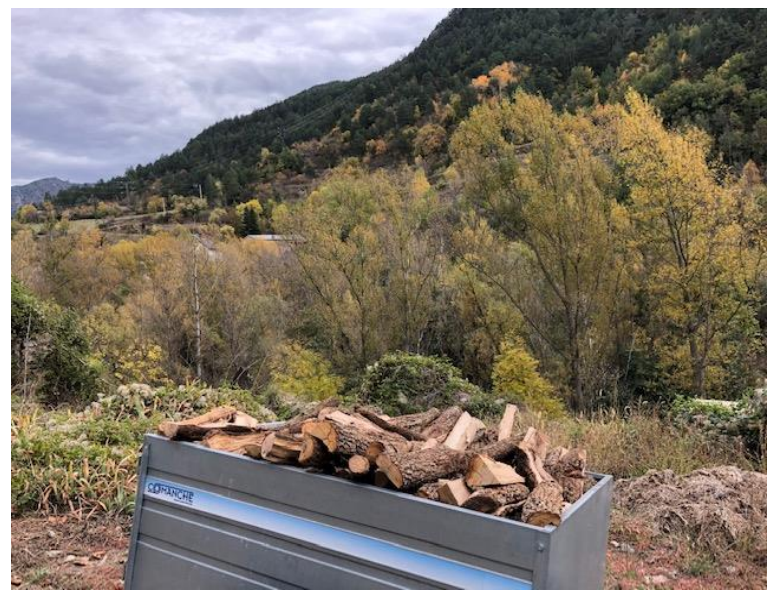

Fig 6. DIY wood management in Alt Urgell (@RicardMoren, 2019)

Interestingly, the current situation in Catalonia and other European countries is quite the opposite of the situation in England during William Shakespeare's times, when climactic and demographic pressures led to the overexploitation of woodlands. This brought about a fuel crisis, environmental controversies and a $96 \%$ increase in wood and timber prices in a twenty-five-year period in the late $16^{\text {th }}$ century (Martin, 2015).

In contrast, today the EU is fostering forests as valuable multi-faceted and multi-purpose ecosystems (Nègre, 2020). Within this context, projects have been undertaken in regions like Catalonia in order to make forests more manageable and profitable ${ }^{14}$, and possibly to prevent wildfires as well.

According to some immigrant entrepreneurs, another type of environmental management action that might need improvement is wildlife management, particularly controlling the bears living in forests. This is a controversial issue, with two clashing sides among both Spaniards and immigrants. Immigrant entrepreneurs with ties to the farming sector are not happy to have wild bears around.

For others, the attractiveness of having wild bears in the Pyrenees to tourists could be better combined with cattle and pastures preservation: "Some people here do not want bears because they put sheep, horses or cows in danger... but getting rid of bears is not the solution... Having bears here is an asset for tourism... it can be dangerous or not [depending on how the issue is managed]" (EC-43-SA-female-NC). This is particularly a big issue in small villages in the Val d'Aran.

Furthermore, hunters are another factor in the complex equation of how different groups of humans and of other living beings can share the mountains. In Catalonia, most woodland is privately owned (OFC, 2020), and some interviewees highlighted hunting as a danger when they take walks around the village: "I do not like walking with my dogs and I start hearing shots... I am afraid for the dogs, we sometimes run away in fear, and for myself, too. I try to be aware [of hunting seasons]" (EC\&SC-31-SA-female-NC). However, other immigrants participate in hunting activities - for example, as a way of defending their crops and cattle from wild boars attacks (EC\&ENV-34-SA-male-NC). In any case, the regulation of hunting licences is still an open debate in Spain, and in other parts of Europe as well, as covered in mass media reports (Navarro, 2020). Apart from all that, the other types of environmental challenges mentioned in the interviews are tackled in the next section.

\footnotetext{
${ }^{13}$ For instance: 'Are not these woods / More free from peril than the envious court?' (II, 1)

14 See, for instance: https://www.paucostafoundation.org/en/ \& http://www.observatoriforestal.cat/\#prod
} 


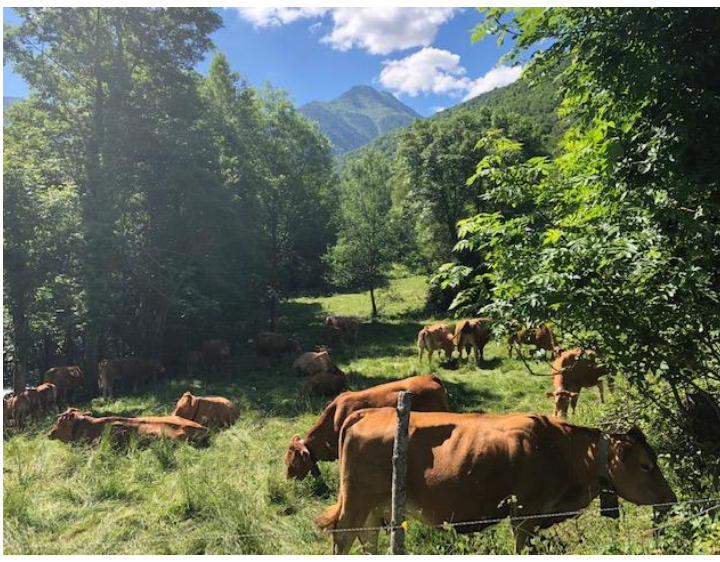

Fig 7. Cattle in pastures of Es Bòrdes, Val d'Aran (@RicardMoren, 2018)

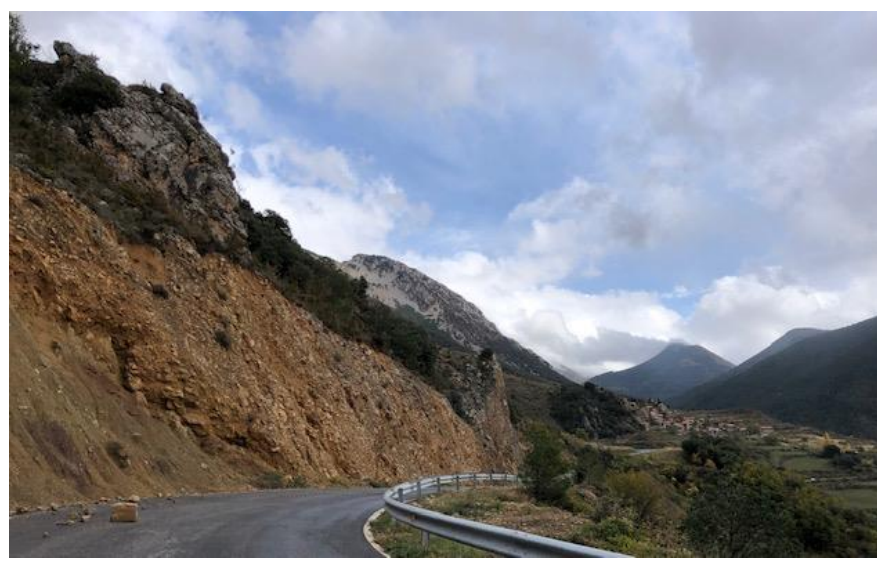

Fig 8. Landslide on a road in Alt Urgell (@RicardMoren, 2019)

\subsubsection{Public transport, road maintenance, environmental education and climate change}

In rural lowlands, public transport can be poor or virtually absent (Morén-Alegret \& Wladyka, 2019), and several immigrant entrepreneurs noted that the situation in some mountain villages is worse. The lack of public transport makes it essential to have at least one private car to go shopping in the county capital once a week (EC-37-SA-female-YC). Apart from having a car to get around, sometimes additional driving skills are needed because some roads are in very bad condition; for example, in some municipalities, drivers regularly have to avoid potholes in the pavement (or landslides), as well as drive on steep roads with tight bends (EC\&SC-45-EUfemale-YC).

However, there is no consensus about improving roads because some interviewees perceive the improvement of (rural) roads as paving the way to the emigration of permanent residents and encouraging second homes (e.g., SC\&EC-68-SA-male-YC). In other villages, a family unit needs several private cars in order to combine the parents' business activities and the children's extracurricular activities: "We have two cars because if my son has to go to the swimming pool [in the county capital] and the ski resort [in the mountains] for his after-school activities, I have to pick him and take him there. My husband needs another car to buy supplies for the business or for other things" (EC-28-EU-female-YC). Interestingly, some gender roles seem to stick to old traditions, and the immigrant women interviewed are more involved in transporting their children to extra-curricular activities located in towns than the immigrant men interviewed.

In addition, coming of age in the mountains also involves getting a driving licence for some children of immigrants (and parents have to pay for it): "This village does not have a school, so we have to bring our children to other places. There is school bus [to the county capital], but apart from that, public transport is awful up here. I mean there are just 2 or 3 buses per day, and the bus stop is down in the main road [about $2 \mathrm{~km}$ from the village]. It is very difficult to organise life with public transport... we spend the day as taxi drivers going back and forth. This is why my 18-yearold son is already taking the exam to get his driving license" (SC\&EC-52-EU-female-YC). 


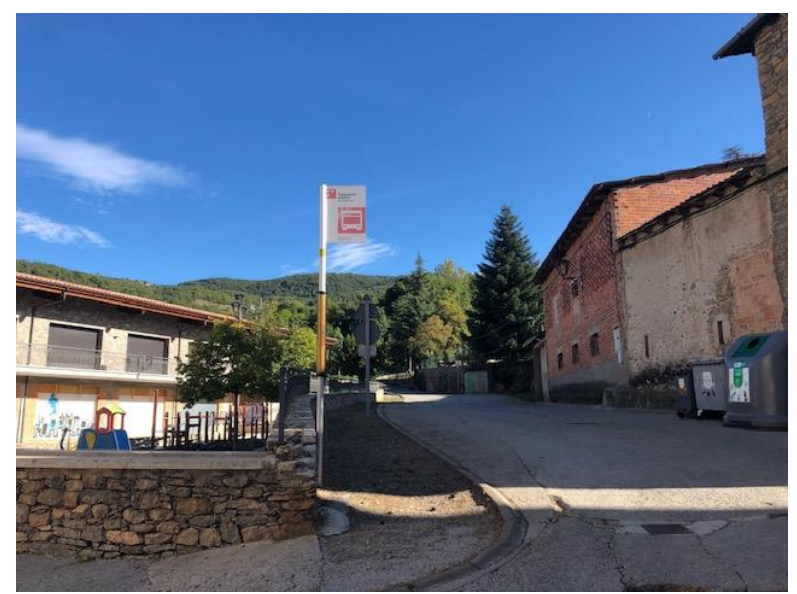

Fig 9. Bus stop in Alàs, Alt Urgell

(@RicardMoren, 2019)

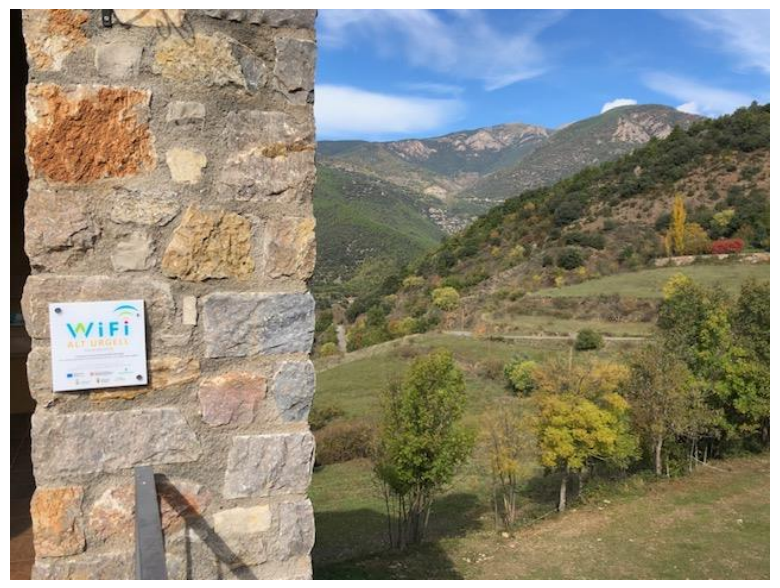

Fig 10. WiFi sign in Arsèguel, Alt Urgell (@RicardMoren, 2019)

Apart from the pollution caused by having several cars running around in the mountains per family unit, the lack of public transport also increases electronic commerce (e-commerce), particularly on-line shopping, which poses other environmental challenges: "In the long term, I don't know if on-line shopping is sustainable... vans travel back and forth just to bring us a little package. Is that sustainable? I do buy things on the Internet and it's fantastic, but at the same time, I have my doubts about it" (SC\&EC-52-EU-female-YC). Today, the environmental impact of e-commerce is still an open public debate in Spain and other European countries, in both urban and rural areas (Montanyà, 2020). Furthermore, some interviewees also indicated that the need to use private cars causes some chaos due to scarce car parking in the village and surrounding areas, particularly in peak touristic periods or when there are country fairs (EC\&SC-31-SA-female-NC). These environmental challenges can also be linked to climate change effects, and improving public transport in rural areas can be a part of climate change mitigation policies. Some immigrant entrepreneurs have already perceived the effects of climate change in the villages where they live as an environmental challenge: "Climate change can be perceived here. Last winter was long and it snowed a lot, a lot. I love snow, but... And this year, in contrast, it snowed at the beginning of winter and then the weather was hot, hotter than usual. Everything was dry, when it isn't usually so dry" (EC\&SC-31-SA-female-NC). However, interestingly, the Lleida Pyrenees are already attracting immigrants escaping the (perceived) more severe effects of climate change in other parts of Catalonia, like 'tiger mosquitoes': 'We used to live near Barcelona, in a leafy suburb, but in summer that place became infested with tiger mosquitoes... That was not the main reason we moved up here to the mountains, it's just an anecdote, but I wanted to find a higher altitude place where there are no tiger mosquitoes" (EC\&SC-40-EU-male-YCAs Ely et al. (1997: 65) alerted us: "Anecdote is a mysterious animal... in the anecdote the nugget of meaning somehow gets put into writing".

Another environmental concern among some immigrants interviewed is the preservation of the current natural and rural landscapes that attracted them to live in the village some time ago: "This is one of the cleanest places l've ever been. One challenge is to keep this place clean and for newcomers to adapt to the place and respect it. Here, you can do tonnes of projects, you can focus businesses ecologically; this is an ideal place for that" (EC-22-SA-male-NC). In this sense, improving newcomers' environmental education is also perceived as a key challenge for the future, particularly if new rural immigrants come from urban areas: "Local institutions could offer more educational activities so they can better adapt to life in these mountains... when I arrived I knew nothing... Later I learnt that in autumn, I can gather mushrooms, in summer there are blackberries" (EC\&SC-31-SA-female-NC).

This environmental education could also be linked to sustainable development adapted to the biodiversity existing in each hamlet and surrounding area. In this context, encouraging decentralised university faculties or departments in the hamlets in the Lleida Pyrenees would be a helpful way to create more innovative businesses (Charles, 2016) and attract a wider variety of inhabitants. This would particularly make sense for university programmes that require practical 
training outdoors, learning from experiences in other countries. In La Seu d'Urgell, there is already an office offering a few degrees from the Spanish distance-learning university known as UNED, ${ }^{15}$ and there are plans for the Lleida University Sports Faculty in La Seu d'Urgell. ${ }^{16}$ However, apart from county, on-site university training could also be offered in mountain hamlets in a wide variety of disciplines, learning from the experience of recent and current (temporary) experiences that usually take place in the summer only. In this sense, in order to spread university teaching and research across sparsely populated mountainous areas, lessons can be learnt from the UABICTA campus in Alinyà, a hamlet in Alt Urgell ${ }^{17}$. This small (temporary) campus has been operating there periodically since 1999.

\subsection{Economic dimension of sustainability}

\subsubsection{DIY mentality, seasonality, economic diversification, labour conditions and sustainable business development}

Particularly in remote hamlets located far from big cities and urban areas, seasonality is a major economic challenge to having more permanent human inhabitants working all year round, which would also reduce pollution: "Suddenly... for instance, in this restaurant... in summer, we have 300 people asking to have lunch at once, it's brutal... Tourism could be managed according to a distribution of places... like in France [with school holidays]... If the holidays were spread over the year, there would be work all the year round. I only have one worker employed all the year round, but with tourists coming throughout the year, I could have two workers all the year round... it would be a way to avoid so many temporary jobs in mountains and valleys like this" (EC-43-SAfemale-NC). However, thanks to weekenders, seasonality is less important in villages that are well connected to urban areas by main roads or located closer to cities: "Tourism here is concentrated in August. However, there are lots of periods in the rest of the year when people come up here: in spring, the weather is nice and in summer, it's fantastic, in autumn, you have mushroom gatherers... in winter, there are skiers around... so there is tourism all year round. There are about 200 registered inhabitants in the village, but there are more than 300 houses, so there are lots of second homes of people living in cities who come at weekends, Christmas, Easter, summer..." (EC-22-SA-male-NC). As explained in another section below, second homes also have side effects for human population sustainability in hamlets.

In any case, among immigrants living in mountain villages, there is somehow a need for a 'Do-ityourself' (DIY) mentality and implementing the art of improvisation, economic diversification, austerity and some sort of internationalisation: "I cannot only depend on working in the restaurant to earn a living because summer is the high season here. The rest of the year you can go to work in the ski resorts [located in the surrounding areas], or else it's very difficult to earn money... but the good thing about living here is that you spend less money than in the city... and the quality of life is much better here... At first, I got a [part-time] job in the restaurant, and then people learnt about my skills, so I was asked to teach art workshops and English" (EC\&SC-31-SA-female-NC). In the UK, the need for a DIY mentality in some rural areas was also acknowledged in the report written by the Select Committee on the Rural Economy linked to the House of Lords (2019), which says that "running a business in a rural area requires a 'do-it-yourself' mentality and that getting support or action from local authorities to get something done involved an amount of pushing that should not be necessary" (p. 209).

\footnotetext{
15 See: http://www.unedseudurgell.es

${ }^{16}$ See: https://www.udl.cat/ca/serveis/oficina/Noticies/Ciencies-de-lactivitat-fisica-i-lesport-simpartira-a-La-SeudUrgell-el-curs-2021-2022/

17 See: http://icta.uab.es/CampusAlinya/index.htm
} 


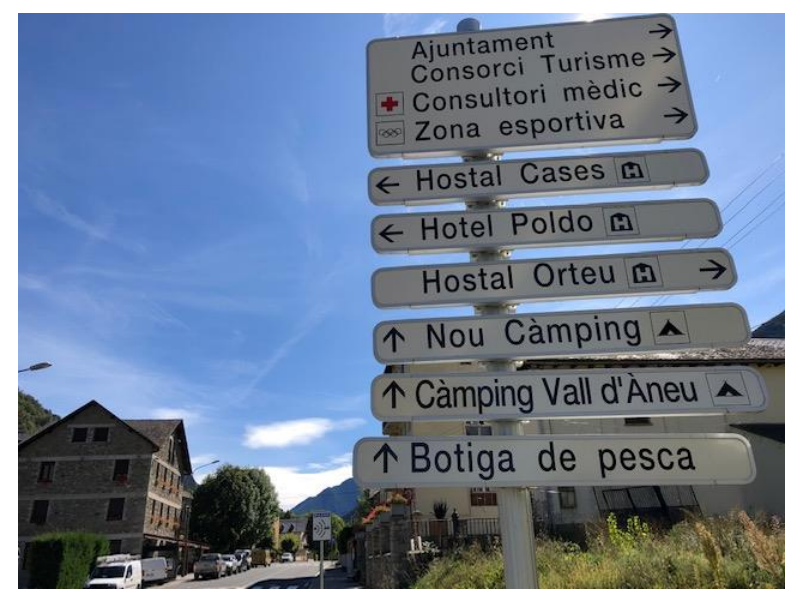

Fig 11. Touristic sign in Guingueta d'Àneu, Pallars Sobirà (@RicardMoren, 2019)

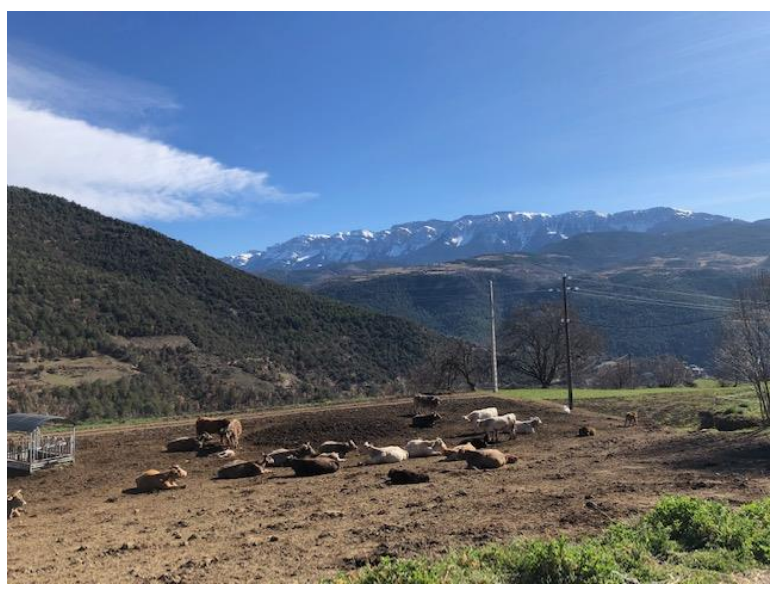

Fig 12. Cattle on a farm in Estamariu, Alt Urgell (@RicardMoren, 2020).

In some cases, multiple jobs, DIY and internationalisation as ways of overcoming seasonality are made possible thanks to the Internet, particularly in hamlets with a fast and reliable broadband connection.

This is the case, for instance, of an immigrant entrepreneur who combines self-employment as computer scientist (offering computer services from home to different organisations based both in Spain and in South America) with a salaried job as waiter in a restaurant in the county capital during the peak summer touristic season: "I have my own company [as a computer programmer] but my children are older now, last summer my mother came to visit us for three months [with a touristic visa, willing to take care of her grandchildren] and most of the organisations I work for are active only during the school year. So I looked for a complementary summer job and I was hired as a waiter in a restaurant" (EC\&ENV-33-SA-male-YC). In other words, one has to adapt to a place where it is difficult to earn money, and at personal or family level, economic diversification is a must, but hamlets are perceived as places where one can save money compared to larger villages or towns, because there are fewer places to spend it (EC\&SC-45-EU-female-YC).

In other cases, the combination of stockbreeding, agriculture and rural tourism is an 'option' for a variety of inhabitants (Tulla, 2019), including for some immigrant entrepreneurs who have access to land and properties (e.g., through marriage to a native inhabitant) and live a relatively austere way of life: "When the cattle prices decrease, obviously our income decreases, but the production costs are the same or more expensive. This is a challenge. And if we do not diversify our economic activity, we would be over-dependent on fluctuating food prices, so we now work in tourism [rural apartments to rent]... Our main aim is not to buy the latest sports car, but to breathe this air, eating this food, have this quietness, interact with friends" (EC\&ENV-34SA-male-NC).

In this sense, some hamlets are seen as lands of opportunity where dreams of the 'slow life' (Mancuso \& Petrini, 2015) and some DIY entrepreneurial projects can come true someday: "In a big city, I can't do my projects because there are already a lot of professionals... we can do more things for ourselves here, we can find more community support here. In the city, when you leave home, everything is ready to be consumed" (SC-42-EU-female-YC). However, there are also newcomers infused with the so-called romantic 'rural idyll' (Bunce, 2003; Farrell et al., 2012; Lampič \& Mrak, 2012; Rye, 2014) who do not arrive with a DIY mentality. That passive, idyllic vision may make that their (long term) immigration project fails because they are not able to actively adapt to the real life in the mountain hamlets. "[In recent years] there have been a lot of people [both from the Barcelona region and other places] who have come to this village with their hands in their pockets, asking: 'What are you going to give us?' They come here with an idea... they come here because they like mountains and such, but they assume that local inhabitants should take care of them, that jobs should be offered to them. Come on! Look, I had to fight and find my own way, nobody offered me a job!" (SC\&EC-68-SA-male-YC). 


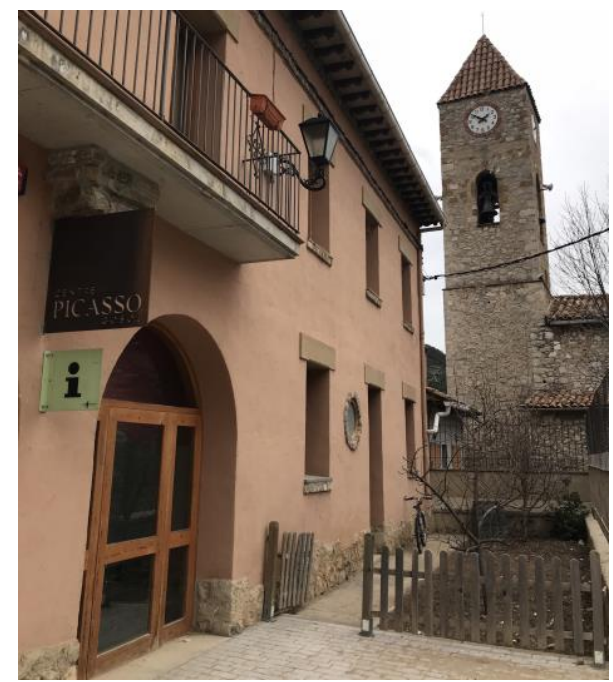

Fig 13. Picasso Museum in Gósol, Berguedà (@RicardMoren, 2018)

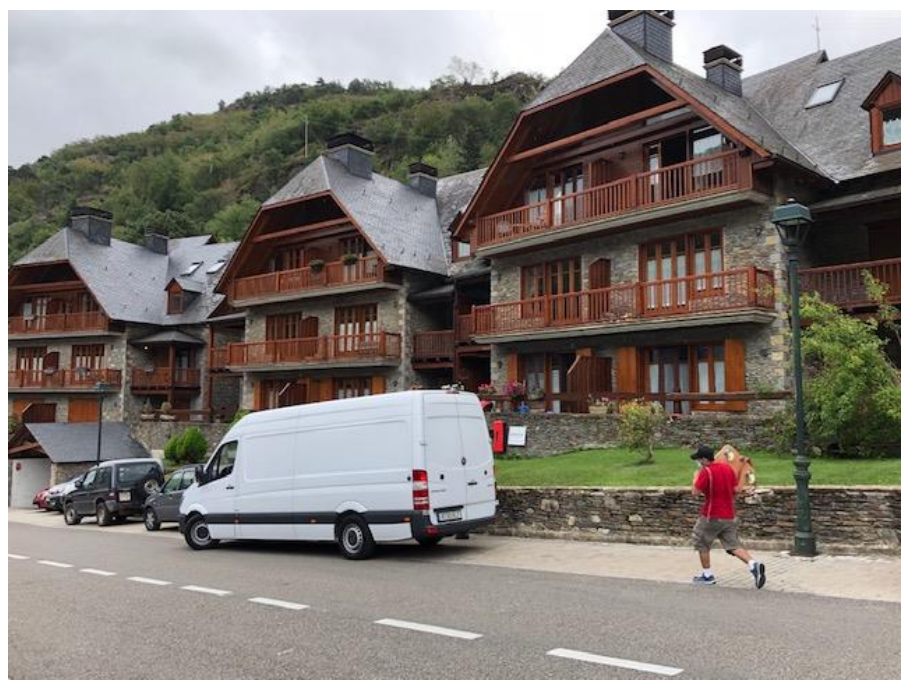

Fig 14. Deliveryman in Es Bòrdes, Val d'Aran (@RicardMoren, 2020)

Bearing that in mind, some immigrant entrepreneurs suggested, the 'place branding', transport services and international promotion of hamlets in need of repopulation should be improved. This would also be helpful for complementing/competing with Andorra, the closest 'cosmopolitan' territory. In addition, better informing citizens about the real socio-economic situation and services available in hamlets would help to prepare potential immigrants for what they can expect to find in daily life in the mountains (e.g., the honest pros and cons for young people thinking about moving to the mountains in order to start life projects): "Proposals like building new mountain railways or a more efficient bus system and a better promotion of the hamlets on the Internet are fundamental" (EC-22-SA-male-NC).

In this regard, another economic challenge cited by some immigrant entrepreneurs is how to organise (international) marketing campaigns promoting the cultural dimension of small villages in order to support artisans and artists' products and services: "More space should be given to local cultural exhibitions, and cultural promotion should be better than it is now... most people [in the Barcelona region] do not know about the exhibitions presented in the village museum" (EC\&SC-31-SA-female-NC). During fieldwork, the researchers visited the official touristic offices in the cities of Lleida and Barcelona and acknowledged that the relatively scarce tourist promotion of the Lleida hamlets is usually focused on the (natural and/or rural) landscapes.

This lack of enough cultural dynamism and interrelation with other regions is perceived together with the economic challenge posed by the fact that most jobs are in the county capitals and larger villages, which turns some hamlets into satellite residential villages of larger human settlements (without endogenous economic development): "People go to work outside of the village. Nothing is developed here economically. There are no services in the village where you can work" (SC42-EU-female-YC). In addition, the worst may be yet to come for some traditional local businesses, because in some hamlets with fast Internet connections, the increase in online shopping may make survival even more difficult for some remaining local shops and services: "Without Internet, we would not live in this hamlet. We are big Internet shoppers... Yesterday night, I bought shoes for my daughters because it saves me time; otherwise I would have to go to Andorra or to the county capital, but the goods available in the county capital aren't very diversified" (SC-42-EU-female-YC).

In this sense, when a hamlet has a bar or a restaurant, these businesses can become points where packages from online shopping are collected, sometimes for free. This happens thanks to mutual help and community life among village residents: "Everything is more expensive in the shops in this county than on the Internet, so everybody tries to shop on the Internet and you can see deliverymen running around the village... Deliverymen know that we are open everyday, so they ask me: 'Can I leave the resident's package here?' And I say 'OK'... Another day it may be the other way round, and a neighbour can help us" (EC-28-EU-female-YC) 
Another economic challenge for sustainability expressed by immigrant entrepreneurs is fostering more long-term projects adapted to mountain life that can bring more new permanent inhabitants. For instance, in hamlets where there is a lot of underused woodland, ideas were suggested for smart harvesting of timber or kindling for heating: "The ski resort heating system already works with kindling. If that works up there, why can't it work in the village? ... Woodlands are dirty. I agree that this is a difficult mountain, but if you bring a work team here to clear the forests [to both promote kindling as fuel and preventing wildfires], tell them that they will have a job here for 15 or 20 years and that they can buy or rent a house here... then you would have three or four families working here all year round. And in winter, when it's very hard to work in the forest, these workers could be employed in the ski resort" (SC\&EC-68-SA-male-YC). In that sense, apart from securing more long-term projects, another perceived challenge for economic sustainability is how higher salaries and/or more profitable activities could be offered in mountainous areas: "Some people pay next to nothing. It seems like you're doing them a favour. No, come on, pay good salaries, working people need to earn a living, people need to live decently in order to provide a good service... Some people say: 'You don't have so many needs up in the mountains'. Why not? I need to get away from time to time and I like to go to the theatre" (SC\&EC-68-SA-male$Y C)$. In fact, as another immigrant entrepreneur stated, improving incomes would help to attract and retain a permanent young population, both for vocational and other jobs: "This is a job that is not well paid, we can barely live on it... What young people would want to do this job with this pathetic income? This is my question. The older people started here as hippies, earning next to nothing, and they are still here for the culture and the country... Right now, carrying out this project in the mountains... should be like a mission" (SC\&EC-52-EU-female-YC).

\subsubsection{Business logistics, Internet connection, access to support/networks/credit and bureaucracy}

In some hamlets located in the Lleida Pyrenees, immigrant entrepreneurs highlight various business-related challenges for economic sustainability, like extraordinary logistical difficulties for businesses located in hamlets that are far away from the county capital and the main roads. For instance, this is a real challenge for some businesses in the restaurant sector, particularly in their first year of existence: "The logistics of bringing goods to our restaurant [located in the centre of the hamlet] is very hard. In summer, our only option was to go down to the county capital everyday in order to buy supplies in shops and supermarkets... Some suppliers don't come here" (EC-43$S A$-female-NC). In this sense, some immigrant entrepreneurs acknowledge that the county council helped them with the red tape of their entrepreneurial projects, but they claim that public administrations should offer more economic support for businesses start-ups in hamlets: "There are plenty of opportunities for new projects here. With a little bit of imagination, you can set up a new business one way or another, but money is lacking. There should be a grant from the state or a subsidy" (EC-22-SA-male-NC). In a similar vein, another immigrant entrepreneur acknowledged that every year they have to visit several municipal councils in the Pyrenees begging for a subsidy to support their projects (SC\&EC-52-EU-female-NC). In addition to the numerous tiers of public administration existing in the Lleida Pyrenees, some immigrant entrepreneurs believe that the groups linked to the European LEADER programme ${ }^{18}$ are helpful for business sustainability in hamlets.

However, other immigrant entrepreneurs think that they should become more long-term mentors and support groups, particularly for young entrepreneurs: "LEADER groups are very important, but more visibility is needed. For instance, if a Catalan friend from the county capital had not introduced me to the people in the LEADER group, I would not have known about it. Take into account that I work with ICT and I am online all day... Once I got in touch with them, they helped me a lot, because they offer you visibility and networking" (EC\&ENV-33-SA-male-YC). In this sense, apart from this institutional and economic support, having access to local personal or social networks is perceived as more difficult in some hamlets in the Pyrenees than in larger villages and towns: "There are jobs here, but they are closed things, they are family jobs. Someone from elsewhere cannot gain access to a job in a hamlet like this. If someone comes to

\footnotetext{
18 See: https://enrd.ec.europa.eu/leader-clld/leader-toolkit/leaderclld-explained_en
} 
live here from the outside, they should look for a job in the county capital, in larger villages or somewhere else" (SC\&EC-52-EU-female-YC). This is a reason why some immigrant entrepreneurs living in hamlets perceive that LEADER groups could be very important for other immigrants, particularly if mentorship is reinforced with a long-term perspective: "I know about some great projects. A few months ago, for instance, I offered technical support to a couple of young guys who came from Barcelona after graduating from university... but three months later they hadn't found any institutional support, everything was so slow, there were so many procedures... that their project died... They were lacking a local mentor" (EC\&ENV-33-SA-male$Y C)$.

Thus patience and adaptation to a slow pace of life are also important skills when developing new businesses in mountain hamlets, including sometimes adapting to slow and intermittent Internet and WiFi connections: "For my artistic business, I have a website and social media like Facebook and Instagram... Mobile phones work well in this part of the village, but not in the outskirts. When there are snowstorms, the electrical grid breaks down... Anyway, I know that the Internet is not going to work here like it does in the city. The Internet is not as fast, but... you can get used to slow Internet access" (EC\&SC-31-SA-female-NC).

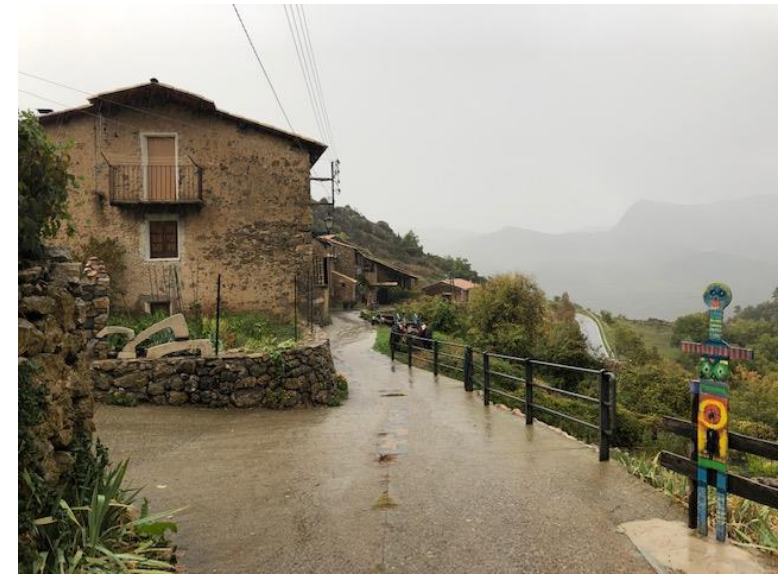

Fig 15. Arts \& crafts in La Vansa-Fórnols, Alt Urgell (@RicardMoren, 2019)

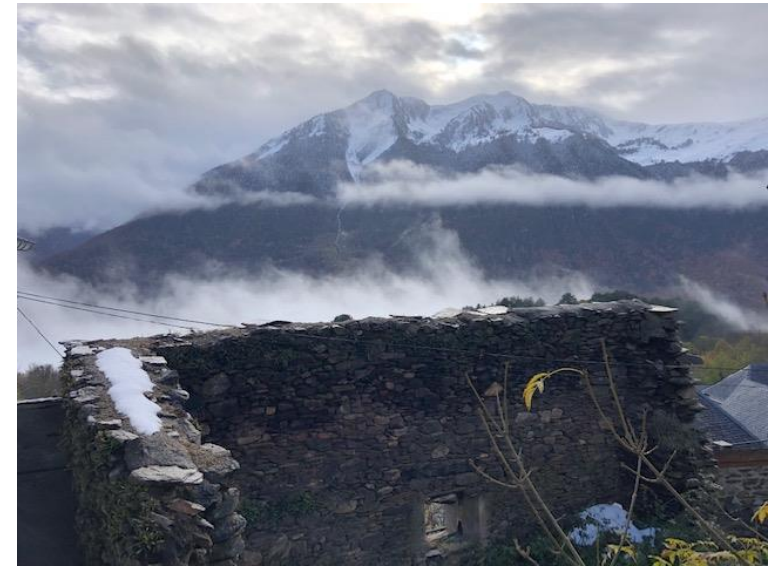

Fig 16. Ruin of an old house in Vilamòs, Val d'Aran (@RicardMoren, 2019)

Apart from adaption to slowness, one way to have faster broadband Internet access is by implementing rural DIY Internet connections, as it happened in the UK (Moss, 2015). In any case, this is an issue that the Catalan Government's 5G strategy has been trying to tackle since $2019,{ }^{19}$ albeit still with uncertain results. In addition to 5G, a semi-public Spanish hi-tech company is planning to open new avenues for businesses in rural Spain by offering fibre optic or broadband services (Álvarez, 2020). However, for some immigrant entrepreneurs with retail business projects, one of the greatest challenges for economic sustainability is the local bureaucracy in some municipalities. Thus, searching for entrepreneur-friendly villages can become a priority before migrating: "We were looking for a quiet place... We were looking for small businesses opportunities. We wanted to work for ourselves. Sometime later we found that in a village near here the municipal council was looking for families with children, but they told us that we had to submit a [business] project. I told them that I didn't want to write projects, and we kept on searching until we found a business opportunity in this hamlet" (EC-37-SA-female-YC). In other words, the attitude of municipal governments matters.

Last but not least, another economic challenge for sustainability in hamlets is gaining access to buildings or lands (to rent or to buy) where (new) businesses can be developed. "Many properties here are owned by an Andorran family because the old landlord died and his properties were inherited by his daughters. They live in Andorra and have several properties here: they own a restaurant that is now empty; they own (tourist) apartments in the main village square; they also

19 See: http://politiquesdigitals.gencat.cat/web/.content/Telecomunicacions/5G/Estrategia-5G-de-Catalunya.pdf 
own a house in that square... I mean that they have a lot of money and a lot of properties here. They don't want to sell" (SC\&EC-52-EU-female-YC).

This issue is not a particularity to the Lleida Pyrenees, but similar problems of access to property (to both rent and sell) in hamlets can be found in other parts of rural and semi-rural Spain as well ${ }^{20}$.

\subsection{Social dimension of sustainability}

\subsubsection{Ageing population, rural schools and youth's prospects}

Among some interviewed immigrant entrepreneurs, the increase in the ageing population in the mountains is a perceived social challenge with several causes, including low birth rates ["in the future, there will be Moroccans, black people and Chinese folks because many Spanish people do not have children" (EC\&ENV-60-SA-female-YC)] as well as the emigration elsewhere of natives and children of foreign immigrants: "My 23-year-old son doesn't want to stay in the village. There is no life for him here anymore... because the situation here is sad for youth... when he comes to visit us [from Andorra] he tells us that he doesn't want to work here, even if he was offered a job" (EC\&SC-45-EU-female-YC).

For young immigrant entrepreneurs who can be considered 'cosmovillagers' one challenge is, combining the possibility of travelling to other places (from time to time) with having permanent jobs or long-term projects in villages or mountainous areas where there are other well-travelled people open to the world: "At first it was hard, I missed having other people my age around and not being able to share certain things, like the arts, museums, exhibitions... But recently, more culture-wise newcomers have arrived. More open-minded people are coming here, more welltravelled people... Now I don't want to leave here anymore... I can travel from time to time, but when I come back here, I feel happier than anywhere else" (EC\&SC-31-SA-female-NC).

In addition, as mentioned in another section above, having a car to get around (or living in a hamlet with frequent public transport services) is also important to young people and the active population: "Young people are few and far between here. I am the only one of my age group in this hamlet. There are other young people in other villages, and others come at weekends, but there are not many... Now I am comfortable, we have a bar... It's like a social club... but I know that this is not the best place to be for people my age because I want to be with more people... I feel isolated, but it's my fault. If I had my driving license, I could get around..." (EC-22-SA-male$N C)$.

Having places for socialisation is important not only to young people but also to the burgeoning retired population. The scarcity or lack of social venues in mountain hamlets may mean that the few bars or restaurants available are over-frequented by the ageing population, putting a lot of pressure on some immigrant bartenders. Problems like working long hours with hardly a single day off may make it difficult for immigrant entrepreneurs who run bars or restaurants have (more) children in hamlets: "There should be a social centre... often if I want to close the bar because I need to take a break, I can't do it because then I would leave the elderly folks without coffee and without the time to socialise, watch TV, comment on the news, talk. The bar is a social space... Sometimes in the summer I am just about burnt out, I work 17 hours... Sometimes I think that I should close the bar and I would only keep the restaurant and the rural apartments, but that would be painful for the elderly people" (EC-43-SA-female-NC). However, in hamlets located near ski resorts or other tourist developments, social venues for young people, the elderly and other villagers are much more frequent than in other hamlets.

\footnotetext{
${ }^{20}$ E.g., see: https://ib3.org/pobles-buits-herencies-runes-centenars-cases-abandonades-part-forana-mallorca
} 


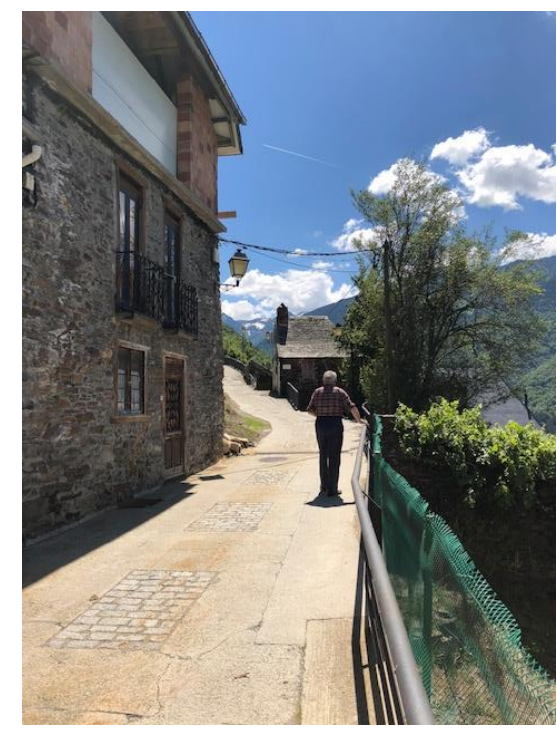

Fig 17. Elderly man walking in Canejan, Vald'Aran (@RicardMoren, 2018)

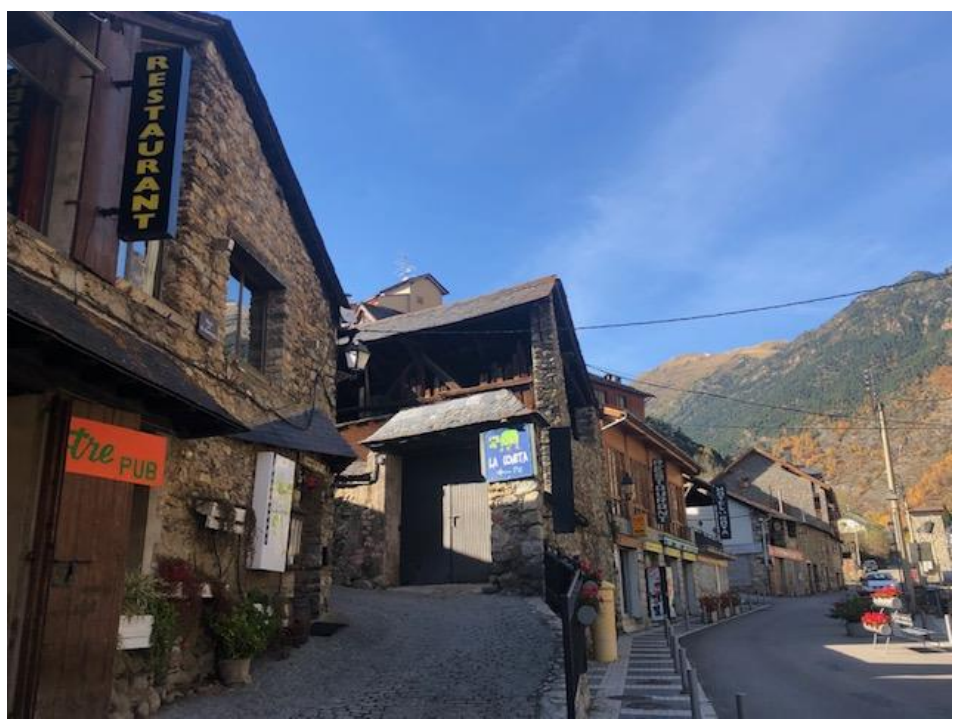

Fig 18. Pubs, restaurants \& hotels in Espot, Pallars Sobirà (@RicardMoren, 2020)

In order to rejuvenate mountain populations in the short or middle term, attracting families with small children is a must, which makes access to schools a key challenge. The importance of the rural schools goes beyond just the educational options available. Rural schools are perceived as sociocultural engines and as seeds of (possible) future sustainable development for the whole village: "When I arrived here [in the mid 1980s], we [as parents] had a lot of cultural initiatives in the school, and today some of them are still there" (SC\&EC-68-SA-male-YC). Thus, a variety of voices say that attracting new children to the village is a priority challenge: "More families should be encouraged to come here in order to rejuvenate the village. The school is small and should be enlarged. This would make more families with children come here" (EC\&ENV-33-SA-male-YC). For some, hamlets that already have a rural school could be made more appealing to families by holding more local activities for children, because parents often have to organise free-time activities themselves (e.g., EC-37-SA-female-YC) and not everybody has time to do so.

In addition, having more playgrounds and sports facilities would help, too (e.g., EC\&ENV-33-SAmale-YC; EC-28-EU-female-YC). However, many hamlets do not have their own school. In some counties, one effective measure to encourage families with children to move to live in hamlets that do not have their own school is offering them free school meals and a school bus to the county capital: "More families with children are coming to live in this hamlet because the bus from the village to the school in the county capital is free for them, and the children registered here are given free meals at school" (EC-43-SA-female-NC). However, this kind of policy can be problematic for rural schools in larger villages if the only way to have a free school bus or meals is by sending the children to schools in the county capital: "There is no school here, and we always wanted to register our children in a rural school [in a larger village] because the school bus is only free if you send your children to the schools in the county capital. During primary school, we drove our children to the other village everyday. There were other families around with the same idea, so we set things up for car sharing" (SC\&EC-52-EU-female-YC). 


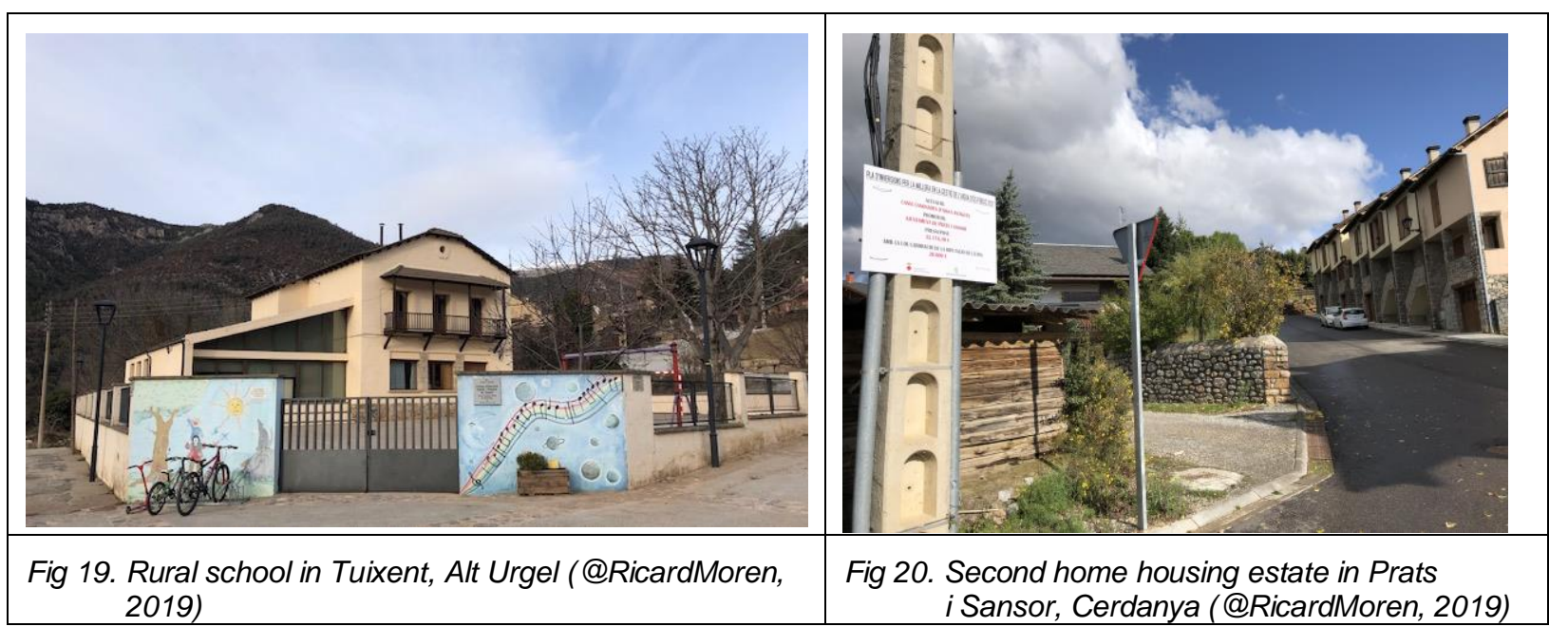

\subsection{2 (Social) housing, individualism, isolation, open/closed social life and (middle class) 'new' (second home) part-time inhabitants from urban areas}

The scarcity of housing both to rent and to sell, rising housing prices and the lack of social housing are also priority challenges for immigrant entrepreneurs living in hamlets in the Lleida Pyrenees. Sometimes the blame is placed on the large number of second homes, which increase the prices of all housing in hamlets, as well as the fact that the few flats available to immigrants are too small to house families with children all year round because they were originally designed as (shortterm) holiday apartments (EC-37-SA-female-YC; EC\&SC-40-EU-male-YC). People looking for housing in the area often contact immigrant entrepreneurs running businesses like village shops, bars or restaurants: "People are always calling me: 'Do you know of anything available?' 'No, there is almost nothing' [either to buy or to rent]... We would like to buy a home here or in another hamlet nearby, but it's hard to find anything" (EC-43-SA-female-NC). In other words, vicious circles should become virtuous circles, but public authorities have to encourage more landlords and empty house owners to rent or sell their properties with incentives (e.g., by offering them guarantees or insurances) or penalties: "Finding rental housing now is very difficult, no matter the village, in the county as a whole, almost nothing can be found... and everything is very expensive... There are jobs here, but there are no flats where you can live... Then people rent a flat or a house and everybody lives there, so they destroy the place because there are too many people, then landlords don't want to rent anymore" (EC-28-EU-female-YC). The lack of sufficient housing is an issue that also affects both Spanish-born and immigrant entrepreneurs wanting to hire (temporary) workers during the peak tourist or farming seasons.

Sometimes in connection with the increasing number of second homes and gentrification processes (see Perlik \& Membretti, 2018), a slow decay or transformation of social life is perceived in some hamlets in the Lleida Pyrenees. At a community level, one immigrant residing in a hamlet for more than 15 years (EC\&SC-45-EU-female) told us that there has been a revival of the local social-cultural association (Comissió de Festes or festivals commission), which was echoed in other stories heard during fieldwork. In the past, when she arrived, most cultural participants were permanent inhabitants (both natives and immigrants), but in recent years, their number has been decreasing (due to emigration or death) and the remaining ones are ageing and/or becoming passive (self-isolating at home, without the interest in or possibility of having relations with weekenders).

The new cultural activists in the village are the (Catalan) second home's owners who usually live in the Barcelona metropolitan region, and most of them only reside in the villages some weekends and holidays. However, traditional cultural activities and celebrations where natives and newcomers from other parts of Catalonia, Spain or abroad share time and space are considered a means of social integration, but only up to certain point: "I keep on thinking that people are quite closed and that I will always be perceived as someone from abroad, even if I work, organise things, have children and family here... This happens in this village and in other villages: there are insiders and outsiders. However, we are quite active in organising Catalan cultural activities, 
which makes me more accepted by the native inhabitants [and internal Catalan immigrants]... but I guess there are things that they don't tell me" (SC\&EC-52-EU-female-YC).

Except in Val d'Aran, a territory that is part of the Occitan linguistic area, in recent years the separatist movement has been growing in Catalonia (e.g. Castañeda \& Megens-Sedor, 2020). This is a socio-political movement mainly comprised of an important sector of the middle class who wants an independent Catalonia. This movement includes part-time urban inhabitants with second homes in the villages of rural Catalonia (e.g., in the Pyrenees). In this context, one challenge for social sustainability in hamlets is how to overcome the linguistic problems related to political conflicts like that: "I never felt bad for not speaking Catalan, but a week ago in a community lunch held in the village, I said 'in Spain people eat a lot of bread' and someone in the table asked me: 'Spain?" I didn't understand if I had said something wrong... I completely forgot the issue of Catalonia, for me this is Spain too... I did not understand that question and he asked me again, and again, until I understood what he meant. I knew nothing about that person. $\mathrm{He}$ is related to this village but is living in Andorra" (EC\&SC-31-SA-female-NC). This 'cosmovillager' immigrant entrepreneur arrived in the hamlet a few years ago, but she has resided several years in various countries apart from her home country in South America, including the USA, the UK, Italy and Spain.

In a small village, almost everybody knows each other, and at times of political polarisation focused on a single issue (e.g., nationalism), politics matter in a different way than in a town or city. In contrast, when a foreign immigrant speaks Catalan, the reaction can be quite different: "I speak Catalan and especially native elderly people are affected and moved when they hear me. A South American speaking Catalan is something exceptional here! This is due to the fact that I speak Catalan well [because I attended school in Catalonia for some years], I speak like a native speaker" (EC-22-SA-male). Interestingly, this young Catalan-speaking immigrant entrepreneur had also lived in several places throughout his life, in both Catalonia and South America, and could be considered a 'cosmovillager' or a transatlantic 'neo-nomad': "I am a neonomad... there are a lot of people like me. I have lived in many places... I am 22 years old and I have moved 18 times" (EC-22-SA-male-NC). In this sense, some rural schools can be considered micro-machines making 'new Catalans' from the children of immigrants thanks to the linguistic immersion and the sociocultural-political movements of recent years in Catalonia: "Most people here voted [on the $1^{\text {st }}$ of October 2017]; obviously I wasn't able to vote, but we helped out. We understand that feeling that people have here, and our children tell us: 'We are Catalans'. Honestly, everybody was working together at that time. We occupied the school for 3 days [around that illegal referendum for independence] (EC\&ENV-33-SA-male-YC). In the next sub-section, other social challenges connected to politics are tackled.

\subsubsection{Opening municipal politics up and encouraging respect for others, instead of prejudice, gossip, racism, classism and sexism}

For some immigrant entrepreneurs, social relations in hamlets are like a 'rollercoaster' because gossip can be difficult to overcome or defuse in sparsely populated regions, where inhabitants are spread across huge areas: "They [locally-born residents] are very closed. At the beginning everybody is nice and kind, but they keep a distance until they know you. Sometimes I have had discussions with people born in the village because I heard from three sources that they were spreading gossips about me... but I asked them directly what was going on ... now they're more careful" (EC-37-SA-female-YC). As William Shakespeare put it in Much Ado about Nothing (V, 1), that 'cosmovillager' might have said to gossipers in her hamlet: "I will leave you now to your gossip-like humour. You break jests as braggarts do their blades ${ }^{21}$, which God be thanked, hurt not". In any case, adapting anti-rumour strategies like the ones already implemented in some cities $^{22}$ to mountain hamlets would be helpful in retaining and increasing the population diversity there. However, ultimately, in remote hamlets where people need each other because outside support is scarce and difficult to find in hard times (e.g. snowstorms), immigrant entrepreneurs

\footnotetext{
${ }^{21}$ In other words, as boasters damage or break their swords themselves to make it look as if they had been fighting (Bate \& Rasmusen, 2007).

22 See: https://www.coe.int/en/web/interculturalcities/anti-rumours
} 
feel the advantage of being part of a community, particularly in municipalities where tourism is not too seasonal: "In the village, people have a narrow mind-set, they are suspicious and less warm, but at the same time people are united. There is gossip... but here people are obliged to interact with each other due to the climatic conditions, like the snow, which makes people come together... more than in coastal villages where people work three months full time and the rest of the year, the villages are almost empty" (EC-22-SA-male-NC).

Unexpectedly, sometimes the 'rollercoaster' may bring immigrants to really dangerous situations linked to racism and classism, which in a small village may be a serious problem, particularly when is related to health issues: "Most people in the hamlet are not educated, but when they see that you are a good worker and that you are not a bad person, they start opening doors to you. In contrast, in the beginning, I went to the doctor [at the local health centre] because my daughter had something and I wanted to know what was going on, and he told me: 'Bring her to the paediatrician'. He told me that he didn't see children... but later I met more people here and I learnt that that doctor was seeing kids in the village, but the other [Spanish] kids. Why not my daughter? Racism... Another South American resident had the same problem" (EC-37-SAfemale-YC). In other cases, racism and classism are 'tamed' thanks to the fact that some immigrants have 'strategic' jobs (e.g. running the only bar for dozens of kilometres around): "With me there is no discrimination because I am who I am, I run the bar, but if I were someone else, who knows... There is a Romanian girl. There are comments about her... Stereotypes... All that upsets me. In a diverse hamlet like this one there should not be that kind of stereotypes because almost nobody was born here... Sometimes I have thrown people out of the bar, they upset me and I do not want those kinds of [racist and sexist] comments here" (EC-43-SA-female-NC). Sometimes racism or xenophobia can also be found together with gossip and sexism, but a kind of stoicism can also be the (sustainable) response to ugly rumours: "There was whispering, but I don't pay much attention. I take care of my family wherever I am... I don't want to argue or fight, and if I have to help them, I help them. Full stop... My [Spanish born] husband has helped me a lot, too. We have helped each other... Some people said that I was only going to stay here a couple of years, that I would steal his money and then move away, silly things. If they're wrong, why should I pay attention to that whispering?" (EC\&ENV-60-SA-female-YC). The fact is that that international couple has been living together in the village for more than 20 years. In any case, socially, apart from improving ethnic relations, another perceived challenge among immigrant entrepreneurs in some hamlets is how to improve gender relations, particularly among adults who could become role models for the younger generations: "There are really no associations here. The women in the village have a WhatsApp group and they get together once a month to have dinner at the bar from $10 \mathrm{pm}$ to 2am, but just women. If you want to have a social life with men here, you have to go to the bar and talk about football, politics or whatever. I don't like to go to the bar... Men's and women's activities are separate" (EC\&SC-40-EU-male-YC).

In order to improve social relations in villages, and to boost the economic and environmental sustainability in the mountains, opening up municipal politics is suggested as a key challenge that has recently started to be slowly tackled in some hamlets after 40 years of democracy in Spain: "Here, the mayor had been in power from the start of democracy [in 1979] until the moment he died [when he was more than 80 years old], about three years ago. For instance, in the last elections, I saw more movement than before because there wasn't just a single person running for office but a group of people [from the same Conservative political party as the previous mayor]" (EC\&ENV-33-SA-male-YC). In some mountain hamlets, municipal elections held in May 2019 have completely overhauled the village councils, which sometimes means that younger people with progressive, innovative ideas are taking office. However, sometimes the political transition can be complicated due to a number of reasons, particularly family matters: "Municipal politics divide people a lot here. I can see things with perspective because I cannot vote... I understand both factions, but there is a struggle that is a challenge for the village... Why do the followers make the problem bigger? ... Like in a Shakespeare's play..." (EC-43-SA-female-NC). When possible, one thing that is perceived as helping to overcome old traditional inertias and/or ancient family feuds in villages is the incorporation of more (internal/international) immigrants on the village councils (i.e. Ayuntamientos): "People on the local council should get more involved. They have to keep on opening the council to the villagers; they are still quite closed, but this year for the first time, councillors born in other parts of the country were elected... They are more open; 
they listen more to the people more than the others" (EC-37-SA-female-YC). On top of all that, in municipalities that include several hamlets, the local political situation can be worse than in municipalities with a single small village. However, some immigrant entrepreneurs may become mediators in ancient conflicts between hamlets: "There were bad times, a lot of conflict, and I became a mediator... Mistakes were made here and I intervened. People in the other village were grateful for that mediation. Over there, all the houses are second homes... but they can vote in elections (SC\&EC-68-SA-male-YC). Having more human diversity matters and, overcoming old conflicts, can contribute to human population sustainability in hamlets, too. In this sense, promoting the long-term duration of immigrants' habitation in the host society is also important (Pascual de Sans \& Cardelús 1987; Layton-Henry, 1990), particularly in depopulating mountainous and rural areas where immigrants are crucial for population renewal (Hugo \& MorénAlegret 2008).

\section{Conclusions and some final remarks}

"Our peace shall stand as firm as rocky mountains"

(William Shakespeare, Henry IV, Part II, IV, 1)

Mountainous areas have inspired peace and higher standards in different countries and times in history, symbolically connecting heaven and earth. However, one can also find stereotypes about mountainfolk being poorer and rougher than people living in lowlands. In contrast to all that, during our fieldwork in small villages in the Lleida Pyrenees, we found active inhabitants who are open to the world (i.e. cosmovillagers), seeking to revive and engage in rural and natural areas, including both well-travelled people born in hamlets and immigrants from other regions and nations. Regarding the latter, most immigrants in the hamlets in the Lleida Pyrenees come from other European countries (mainly from other EU member states) and the Americas, primarily from South America.

Social and economic openness can be related to the development of internationalised sectors like export agriculture or international tourism (Perlik \& Membretti, 2018; Morén-Alegret \& Wladyka, 2019; Tulla, 2019; Romagosa et al., 2020), as well as to cultural, educational and artistic projects and services. Throughout the pages of this paper, the main aim has been to showcase a variety of experiences that are qualitatively relevant to better understand both human diversity and the sustainability challenges and opportunities in mountainous areas. These shared experiences are food for thought.

In summary, territories can be advertised as products in (tourist) marketing campaigns, but as Elden (2018) suggests, territories are not products, but processes made up of a range of practices and techniques. Thus, it should be acknowledged more today than in the past that important practices performed by a range of international immigrants and other cosmovillagers can be found among the practices in the sparsely populated municipalities in the Lleida Pyrenees. Some of them can be performing as active 'cosmovillagers' (Benedí, 2019) and/or 'rural cosmopolitans' (Cid-Aguayo, 2008) at once, but at the same time, some of them can also be performing as 'nationalistic' actors in order to gain local acceptance in times of relatively powerful Catalan separatist movements. This should be taken more into account in order to design future sustainable development policies in mountainous areas, in other words, in order to achieve sustainable rural development. Apart from quantity, human diversity and quality matter, too.

\section{Acknowledgements}

This paper is based upon the research project titled "HAMLETS. Immigration and Sustainable Development in Small Villages" (see: www.uab.cat/hamlets), funded by the RecerCaixa Programme (2017-2020) and being conducted at the Autonomous University of Barcelona (UAB) under the direction of Ricard Morén-Alegret. The RecerCaixa Programme is an initiative of 'la Caixa' Foundation and the Association of Public Universities in Catalonia (ACUP), Spain. Specifically, this project was mainly carried out from the UAB Department of Geography, ICTA and the ECONECOL Consolidated Research Group (AGAUR). The authors are also grateful to 
the interviewees, the Association of Small Villages in Catalonia (www.micropobles.cat), the Association of Mountainous Municipalities in Spain (www.esmontañas.org), the General Council of Aran, the Local Action Group of Alt Urgell - Cerdanya (LEADER Programme), the Community of Municipalities in Cardós Valleys and other Lleida Pyrenees municipalities for their time and collaboration. In addition, this article is also linked to the Transmena research project, funded by the Spanish Ministry for Economy, ref. HAR2016-77876-P.

\section{Academic references}

[1] Adams, W. M. (2006). The Future of Sustainability [Report of the International Union for the Conservation of Nature Renowned Thinkers Meeting]. Gland: IUCN.

[2] Aldomà, I. (2015). Atles de la Nova Ruralitat, $2^{\text {nd }}$ ed. Lleida: FMR.

[3] Badia, A., Pèlachs, A., Vera, A., Tulla, A. F. \& Soriano, J. M. (2014). Cambios en los usos y cubiertas del suelo y los efectos en la vulberabilidad de las comarcas de montaña de Cataluña. Pirineos, 169, Art. 001. DOI: 10.3989/Pirineos.2014.169001.

[4] Bates, J. \& Rasmussen, E., eds. (2007). William Shakespeare Complete Works. Houndmills, UK: Macmillan / RSC.

[5] Bayona-i-Carrasco, J. \& Gil-Alonso, F. (2013). Is Foreign Immigration the Solution to Rural Depopulation? Sociologia Ruralis, 53(1), 26-51. DOI: 10.1111/j.1467-9523.2012.00577.x.

[6] Becker, E., Jahn, T., Stiess, I. \& Wehling, P. (1997). Sustainability: a cross-disciplinary concept for social transformations [MOST policy paper]. Paris: UNESCO.

[7] Berthomière, W. \& Imbert, C. (2020). Le refuge ariégeois: atout et diversité d'une topographie de l'accueil. Journal of Alpine Research, 108(2). DOI: 10.4000/rga.7003.

[8] Bielza de Ory, V. (1993). De la organización del Pirineo en el pasado a la ordenación de su territorio en el futuro. Geographicalia, 30, 47-57.

[9] Bunce, M. (2003). Reproducing Rural Idylls. In Cloke, P., ed., Country Visions (pp. 14-30). New York: Pearson.

[10] Camarero, L. \& Sampedro, R. (2019). Despoblación y ruralidad transnacional. Economía Agraria y Recursos Naturales, 19(1), 59-82. DOI: 10.7201/earn.2019.01.04.

[11] Carson, D. A., Carson, D. B. \& Eimermann, M. (2018). International winter tourism entrepreneurs in northern Sweden. Scandinavian Journal of Hospitality and Tourism, 18(2), 183-198. DOI: 10.1080/15022250.2017.1339503.

[12] Champion, T. \& Hugo, G., eds. (2004). New Forms of Urbanization. Aldershot / Burlington: Ashgate.

[13] Charles, D. (2016). The rural university campus and support for rural innovation. Science and Public Policy, 43(6), 763-773. DOI: 10.1093/scipol/scw017.

[14] Cid-Aguayo, B. E. (2008). Global Villages and Rural Cosmopolitanism, Globalizations, 5(4), 541-554. DOI: 10.1080/14747730802500281.

[15] Connel, J. \& McManus, P. (2011). Rural revival? Farnham, UK / Burlington, US: Ashgate.

[16] Elden, S. (2018). Shakespearean Territories. Chicago, USA / London, UK: The University of Chicago Press.

[17] Farrell, M., Mahon, M. \& McDonagh, J. (2012). The rural as a return migration destination. European Countryside, 4(1), 31-44. DOI: 10.2478/v10091-012-0012-9.

[18] González-Hidalgo, M., Otero, I. \& Kallis, G. (2014). Seeing beyond the smoke. Environment and Planning A, 46(5), 1014-1031. DOI: 10.1068/a45600. 
[19] Gretter, A., Machold, I., Membretti, A. \& Dax, T. (2017). Pathways of immigration in the Alps and Carpathians. Mountain Research and Development, 37(4), 396-405. DOI: 10.1659/MRD-JOURNAL-D-17-00031.1.

[20] Guirado, C. \& Tulla, A. (2010). Entre l'abandonament i l'ús intensiu del territori? Documents d'Anàlisi Geogràfica, 56(3), 607-623.

[21] Halfacree, K. (2008). To Revitalise Counterurbanisation Research? Population, Space and Place, 14(6), 479-496. DOI: 10.1002/psp.501.

[22] Hugo, G. \& Morén-Alegret, R. (2008). International Migration to Non-Metropolitan Areas of High Income Countries. Population, Space and Place, 14(6), 473-477. DOI: $10.1002 / p s p .515$.

[23] Kalantaridis, C. \& Bika, Z. (2011). Entrepreneurial origin and the configuration of innovation in rural areas. Environment and Planning A, 43(4), 866-884. DOI: 10.1068/a43341.

[24] Kallis, G., Gómez-Baggethun, E. \& Zografos, C. (2013). To value or not to value? That is not the question. Ecological Economics, 94, 97-105. DOI: 10.1016/j.ecolecon.2013.07.002.

[25] Kasimis, C. (2010). Demographic trends in rural Europe and international migration to rural areas. Agriregionieuropa, 6(21).

[26] Kordel, S., Weidinger, T. \& Jelen, I., eds. (2018). Processes of Immigration in Rural Europe. Newcastle-upon-Tyne: Cambridge Scholars Publishing.

[27] Lampič, B. \& Mrak, I. (2012). Globalization and Foreign Amenity Migrants. European Countryside, 4(1), 45-56. DOI: 10.2478/v10091-012-0013-8.

[28] Lardiés, R. (2018). Rural Depopulation in Spain. In Kordel, S., Weidinger, T. \& Jelen, I., eds., Processes of Immigration in Rural Europe (pp. 140-157). Newcastle-upon-Tyne: Cambridge Scholars Publishing.

[29] Layton-Henry, Z., ed. (1990). The Political Rights of Migrant Workers in Western Europe. London: Sage.

[30] Lluvich, E. \& Ortega, M. (2004). Els nous rurals del Pallars Sobirà. Barcelona: Generalitat de Catalunya.

[31] McAreavey, R. (2017). New Immigration Destinations. London: Routledge.

[32] Mancuso, S. \& Petrini, C. (2015). Biodiversi. Florence \& Milan: Giunti Editore / Slow Food Editore.

[33] Mármol, C. del (2019). Cultivating Disconnection. In Lobo-Guerrero, L., Alt, S. \& Meijer, M., eds., Imaginaries of connectivity (pp. 177-198). London: Rowman \& Littlefield.

[34] Martin, R. (2015). Shakespeare and Ecology. Oxford, UK: Oxford University Press.

[35] Mendoza, C., Morén-Alegret, R. \& McAreavey, R. (2020). (Lifestyle) immigrant entrepreneurs in Spanish small villages. BELGEO 21(1). DOI: 10.4000/belgeo.44107.

[36] Mendoza, C. \& Morén-Alegret, R. (2013). Exploring methods and techniques for the analysis of sense of place and migration. Progress in Human Geography, 37(6), 762-785. DOI: 10.1177 .0309132512473867$.

[37] Milazzo, J. (2015). Du context villageois au village global. E-migrinter, 13. DOI: 10.4000/emigrinter.545.

[38] Morén-Alegret, R. (2008). Ruralphilia and Urbophobia versus Urbophilia and Ruralphobia? Lessons from Immigrant Integration Processes in Small Towns and Rural Areas in Spain, Population, Space and Place, 14 (6), 537-552.

[39] Morén-Alegret, R. \& Wladyka, D. (2019). International Immigration, Integration and Sustainability in Small Towns and Villages. London: Palgrave Macmillan.

[40] Nori, M. (2017). Immigrant Shepherds in Southern Europe. Berlin: Heinrich Böll Foundation. 
[41] Perlik, M. \& Membretti, A. (2018). Migration by Necessity and by Force to Mountain Areas. Mountain Research and Development, 38(3), 250-264.

[42] Ordi, J., Lluvich, M. \& Lluvich, E. (2015). Arrelats. Sort: Cambuleta.

[43] Pascual de Sans, À. \& Cardelús, J. (1987). El marc dels desplaçaments de població a Catalunya. In Rotger, J. M., ed., Visió de Catalunya. Barcelona: Diputació de Barcelona.

[44] Queralt, R. (1999). Impacte ambiental del despoblament. Lleida: Pagès editors.

[45] Ragin, C. C. (1994). Constructing Social Research - the Unity and Diversity of Method. Thousand Oaks: Pine Forge Press.

[46] Robinson, J. (2016). Theatre and the Rural. London: Palgrave Macmillan.

[47] Romagosa, F., Mendoza, C., Mojica, L. \& Morén-Alegret, R. (2020). Inmigración internacional y turismo en espacios rurales. Cuadernos de Turismo, 46, 319-347. DOI: $10.6018 /$ turismo.451861.

[48] Rye, J. F. (2014). The Western European Countryside from an Eastern European Perspective. European Countryside, 6(4), 327-346. DOI: 10.2478/euco-2014-0018.

[49] Solé, A. (2013). Estrangers a la muntanya [unpublished PhD thesis]. Bellaterra: Universitat Autònoma de Barcelona.

[50] Soriano, J. M. et al. (1994). Medi físic i poblament en un municipi de muntanya. Treballs de la Societat Catalana de Geografia, 9(37), 149-164.

[51] Tulla, A. F. (2019). Sustainable rural development requires value-added activities linked with comparative advantage. European Countryside, 11(2), 229-256. DOI: 10.2478/euco-20190012.

Other sources

[52] Álvarez, R. (2020). Hispasat participará en el despliegue del 5G, La Vanguardia. Dinero, 8 November 2020, p. 10.

[53] Benedí, S. (2019). Cosmopueblita, El Diario.es, 15 January 2019 (https://www.eldiario.es/aragon/elprismatico/Cosmopueblitas_6_857474272.html).

[54] Col-legi de Geògrafs (2013). Micropobles. Elements per a un debat, Barcelona: CdG.

[55] Elcacho, J. (2020). Invertir en sanejament i gestió de l'aigua, un repte global i local, La Vanguardia. Diners, 22 November 2020, pp. 17-18.

[56] EUROSTAT (2017). Sustainable Development in the European Union. Luxembourg: Publications Office of the EU.

[57] EUROSTAT (2016). Sustainable Development in the European Union. Luxembourg: Publications Office of the EU.

[58] FAO (2011). Why invest in mountain sustainable development?. Rome: Food and Agriculture Organisation.

[59] Fuertes, P. (2019). Posibilitar la conciliación, clave para las familias que se asienten en los municipios, Diario de Teruel, 7 April 2019, p. 8.

[60] Montanyà, O. (2020). Los grandes retos del comercio electrónico, La Vanguardia. Dinero, 15 November 2020, p. 11.

[61] Mosler Vidal, E. (2018). Migration and the 2030 Agenda, Geneva: International Organization for Migration, IOM / Swiss Agency for Development and Cooperation, SDC. 
[62] Moss, S. (2015). Want superfast broadband? Do it yourself, BBC Business, 21 September 2015 (https://www.bbc.com/news/business-34256790).

[63] Navarro, J. (2020). La caza pierde balas, El País. El Periódico Global, n¹5819, 7 November 2020, p. 23.

[64] Nègre, F. (2020). The European Union and Forests, Brussels: European Parliament (https://www.europarl.europa.eu/ftu/pdf/en/FTU_3.2.11.pdf).

[65] OFC (2020). Catalunya, un país de boscos, Solsona: CTFC (http://www.observatoriforestal.cat/resum-del-sector/).

[66] Serena, M. \& Bayer, E. (2016). Microcatalunya. Un viatge pels pobles més petits, La Bisbal d'Empordà: Sidillà Edicions, $2^{\text {nd }}$ edition.

[67] UN (2015). Transforming Our World, New York: United Nations, A/RES/70/1.

[68] UNU-GCM (2015). Practicing diversity [policy brief]. Second Mayoral Forum on Mobility, Migration and Development, Quito, Ecuador, 12-13 November 2015. 